\title{
A steady-state continuous flow chamber for the study of daytime and nighttime chemistry under atmospherically relevant NO levels
}

\author{
Xuan Zhang ${ }^{1, *}$, John Ortega ${ }^{1, *}$, Yuanlong Huang ${ }^{2}$, Stephen Shertz ${ }^{1}$, Geoffrey S. Tyndall ${ }^{1}$, and John J. Orlando ${ }^{1}$ \\ ${ }^{1}$ Atmospheric Chemistry Observation \& Modeling Laboratory (ACOM), National Center for Atmospheric Research (NCAR), \\ Boulder, CO, USA \\ ${ }^{2}$ Department of Environmental Science and Engineering, California Institute of Technology, Pasadena, CA, USA \\ *These authors contributed equally to this work.
}

Correspondence: Xuan Zhang (xuanz@ucar.edu)

Received: 9 January 2018 - Discussion started: 12 January 2018

Revised: 4 April 2018 - Accepted: 6 April 2018 - Published: 3 May 2018

\begin{abstract}
Experiments performed in laboratory chambers have contributed significantly to the understanding of the fundamental kinetics and mechanisms of the chemical reactions occurring in the atmosphere. Two chemical regimes, classified as "high-NO" vs. "zero-NO" conditions, have been extensively studied in previous chamber experiments. Results derived from these two chemical scenarios are widely parameterized in chemical transport models to represent key atmospheric processes in urban and pristine environments. As the anthropogenic $\mathrm{NO}_{x}$ emissions in the United States have decreased remarkably in the past few decades, the classic "high-NO" and "zero-NO" conditions are no longer applicable to many regions that are constantly impacted by both polluted and background air masses. We present here the development and characterization of the NCAR Atmospheric Simulation Chamber, which is operated in steady-state continuous flow mode for the study of atmospheric chemistry under "intermediate NO" conditions. This particular chemical regime is characterized by constant sub-ppb levels of NO and can be created in the chamber by precise control of the inflow NO concentration and the ratio of chamber mixing to residence timescales. Over the range of conditions achievable in the chamber, the lifetime of peroxy radicals $\left(\mathrm{RO}_{2}\right)$, a key intermediate from the atmospheric degradation of volatile organic compounds (VOCs), can be extended to several minutes, and a diverse array of reaction pathways, including unimolecular pathways and bimolecular reactions with $\mathrm{NO}$ and $\mathrm{HO}_{2}$, can thus be explored. Characterization experiments under photolytic and dark conditions were performed and, in conjunction with model predictions, provide a basis for in-
\end{abstract}

terpretation of prevailing atmospheric processes in environments with intertwined biogenic and anthropogenic activities. We demonstrate the proof of concept of the steady-state continuous flow chamber operation through measurements of major first-generation products, methacrolein (MACR) and methyl vinyl ketone (MVK), from $\mathrm{OH}-$ and $\mathrm{NO}_{3}$-initiated oxidation of isoprene.

\section{Introduction}

With the discovery of the role of biogenic volatile organic compounds (BVOCs) in urban photochemical smog (Chameides et al., 1988), the interactions of biogenic emissions with manmade pollution and their subsequent impact on the atmosphere's oxidative capacity and aerosol burden have received extensive studies in the ensuing decades (De Gouw et al., 2005; Ng et al., 2007; Goldstein et al., 2009; Surratt et al., 2010; Rollins et al., 2012; Shilling et al., 2013; $\mathrm{Xu}$ et al., 2015). A particular research focus has been understanding the influence of nitrogen oxides $\left(\mathrm{NO}_{x}=\mathrm{NO}+\mathrm{NO}_{2}\right)$ on the atmospheric oxidation cascades of BVOCs, which ultimately generate ozone $\left(\mathrm{O}_{3}\right)$ and secondary organic aerosols (SOA). Nitrogen oxides alter the distribution of BVOC oxidation products by primarily modulating the fate of peroxy radicals $\left(\mathrm{RO}_{2}\right)$, a key intermediate produced from the atmospheric degradation of VOCs by major oxidants including $\mathrm{OH}, \mathrm{O}_{3}$, and $\mathrm{NO}_{3}$. In the absence of $\mathrm{NO}_{x}, \mathrm{RO}_{2}$ reacts predominantly with $\mathrm{HO}_{2}$ radicals yielding organic peroxides and other products and, to a lesser extent, undergoes self- or 
cross-reactions yielding carbonyls, alcohols, and multifunctional species. In the presence of elevated $\mathrm{NO}_{x}$, the dominant fate of $\mathrm{RO}_{2}$ is to react with $\mathrm{NO}$ leading to ozone production, and also to organic nitrates. During the night, $\mathrm{RO}_{2}$ also reacts with $\mathrm{NO}_{3}$ which is produced by the reaction between $\mathrm{O}_{3}$ and $\mathrm{NO}_{2}$. In addition, reaction of peroxyacyl radicals $\left(\mathrm{RC}(\mathrm{O}) \mathrm{O}_{2}\right)$ with $\mathrm{NO}_{2}$ produces peroxyacyl nitrates that constitute a large reservoir of reactive nitrogen and a potentially important SOA precursor (Singh and Hanst, 1981; Nguyen et al., 2015).

Much of our understanding of the extent to which $\mathrm{NO}_{x}$ mediates the oxidation chemistry of BVOC in the atmosphere has been derived from measurements in laboratory chambers, where two extreme experimental conditions, i.e., "high-NO" vs. "zero-NO", were mostly performed to examine the reaction pathways of $\mathrm{RO}_{2}$ radicals (Kroll and Seinfeld, 2008; Orlando and Tyndall, 2012; Ziemann and Atkinson, 2012). Results from these two chemical regimes have been widely incorporated into chemical transport models to represent key atmospheric processes in urban and pristine environments, respectively (Kanakidou et al., 2005). In the actual atmosphere, however, the fate of $\mathrm{RO}_{2}$ radicals is rather more complicated than simply undergoing bimolecular reactions with $\mathrm{NO} / \mathrm{HO}_{2}$ as observed under the two extreme chamber conditions. It has been recently revealed that $\mathrm{RO}_{2}$ radicals may undergo an internal $\mathrm{H}$-shift followed by sequential $\mathrm{O}_{2}$ addition, leading to highly oxygenated multifunctional peroxides (Ehn et al., 2014; Jokinen et al., 2015; Kurtén et al., 2015; Kirkby et al., 2016; Zhang et al., 2017). The rate of H-shift largely depends on the thermochemistry of the nascent alkyl radicals and can be reasonably fast, on a timescale of seconds to minutes (Crounse et al., 2013). Further, depending on the stability of the $\mathrm{RO}_{2}$ precursor (alkyl radicals), $\mathrm{RO}_{2}$ radicals may lose $\mathrm{O}_{2}$ in competition with bimolecular reactions with $\mathrm{NO}, \mathrm{NO}_{3}, \mathrm{RO}_{2}$, and $\mathrm{HO}_{2}$. Recent theoretical and laboratory studies have found that the hydroxy peroxy radical conformers produced from isoprene photooxidation decompose readily to allylic radicals on timescales faster than bimolecular processes under atmospherically relevant $\mathrm{NO}$ and $\mathrm{HO}_{2}$ levels (tens to hundreds of parts per trillion by volume). This highly dynamic system leads to formation of distinctly different products that depend on the concentrations of bimolecular reaction partners from those observed in chamber experiments under "highNO" and "zero-NO" conditions (Teng et al., 2017).

Anthropogenic $\mathrm{NO}_{x}$ emissions in the United States have decreased remarkably in the past few decades (EPA, 2014), resulting in significant changes in the degradation mechanisms of BVOCs, especially in regions impacted by both background and polluted air masses such as the southeastern United States. However, the ultimate fate of peroxy radicals in environments with sub-ppb NO levels is still poorly constrained, in part due to a lack of consistent measurements under well-controlled conditions. Experimental approaches targeting a controlled NO level (sub-ppb to ppb) have been introduced over the years. For outdoor chambers, experiments were typically performed by exposing a gas mixture of $\mathrm{O}_{3} / \mathrm{NO}_{x} /$ VOCs or HONO / $\mathrm{NO}_{x} /$ VOCs to natural sunlight (Bloss et al., 2005; Karl et al., 2006). OH radicals were produced either via the photolysis of ozone and subsequent reaction of $\mathrm{O}\left({ }^{1} \mathrm{D}\right)$ with $\mathrm{H}_{2} \mathrm{O}$ or directly from the photolysis of HONO. NO levels ranging from a few hundreds of ppt to a few ppb over the course of several hours of reactions have been reported. In the absence of any additional supply, NO will be eventually depleted in a closed chamber environment, and the initial "moderate-NO" condition will essentially transfer to the "zero-NO" condition. For indoor chambers, a "slow chemistry" scenario initiated by photolyzing methyl nitrite $\left(\mathrm{CH}_{3} \mathrm{ONO}\right)$ under extremely low UV intensities as the $\mathrm{OH}$ radical source $\left(J_{\mathrm{CH}_{3} \mathrm{ONO}} \sim\right.$ $10^{-5} \mathrm{~s}^{-1}$ ) was created to study the autoxidation chemistry of peroxy radicals produced from isoprene photooxidation (Crounse et al., 2011, 2012; Teng et al., 2017). The resulting $\mathrm{NO}$ and $\mathrm{HO}_{2}$ mixing ratios are maintained at $\sim$ ppt level $\left(\mathrm{CH}_{3} \mathrm{ONO}+\mathrm{O}_{2}+h v \rightarrow \mathrm{HO}_{2}+\mathrm{NO}+\mathrm{HCHO}\right)$ over the course of several hours of reaction, and the average $\mathrm{OH}$ concentration $\left(\mathrm{OH} \sim 10^{5}\right.$ molec $\left.\mathrm{cm}^{-3}\right)$ is approximately 1 order of magnitude lower than that in the typical daytime ambient atmosphere. Another example relates to a recent method development in the potential aerosol mass (PAM) flow tube reactor where nitrous oxide $\left(\mathrm{N}_{2} \mathrm{O}\right)$ was used to produce $\sim \mathrm{ppb}$ level of $\mathrm{NO}\left(\mathrm{O}_{3}+h v \rightarrow \mathrm{O}_{2}+\mathrm{O}\left({ }^{1} \mathrm{D}\right) ; \mathrm{O}\left({ }^{1} \mathrm{D}\right)+\mathrm{N}_{2} \mathrm{O} \rightarrow 2 \mathrm{NO}\right)$ (Lambe et al., 2017). Timescales for chemical reactions and gas-particle partitioning are ultimately limited to the mean residence time $(\sim 80 \mathrm{~s})$ of the PAM reactor.

An alternative experimental platform to the batch-mode chamber and flow tube reactor described above is a wellmixed steady-state chamber with continuous feed of reactants and continuous withdrawal of reactor contents (Shilling et al., 2008). An attribute of the continuous flow steadystate chamber is that, by control of the inlet reactant concentrations and the ratio of mixing to residence timescales, it is possible to simulate atmospheric oxidation under stable conditions over a wide range of time periods and chemical scenarios. For example, a steady-state NO level at $\sim 1 \mathrm{ppb}$ was created by the continuously mixed flow chamber operation for the study of isoprene photooxidation chemistry (Liu et al., 2013). In this study, we present the development and characterization of the NCAR Atmospheric Simulation Chamber, which is operated in steady-state continuous flow mode for simulating atmospheric daytime and nighttime chemistry over chemical regimes not accessible in static chamber experiments. We focus on establishing an "intermediate NO" regime characterized by a constant steady-state NO level ranging from tens of ppt to a few ppb in the chamber. This particular chemical regime is well suited for the study of atmospheric behavior of $\mathrm{RO}_{2}$ radicals, as they can survive up to minutes and embrace various reaction possibilities as opposed to reaction with $\mathrm{NO}, \mathrm{NO}_{3}, \mathrm{HO}_{2}$, and $\mathrm{RO}_{2}$ as their dominant fate observed in most batch-mode chamber 
experiments. We employ the "intermediate NO" regimes to reexamine the daytime and nocturnal chemistry of isoprene through the measurements of two first-generation products, methacrolein (MACR) and methyl vinyl ketone (MVK).

\section{Experimental}

\subsection{NCAR Atmospheric Simulation Chamber facilities}

The NCAR Atmospheric Simulation Chamber consists of a $10 \mathrm{~m}^{3}$ FEP Teflon (0.005 in. thick) bag that is housed in a cubic enclosure with UV reflective surfaces and a bank of 128 wall-mounted blacklight tubes ( $32 \mathrm{~W}$, type F32T8/BL). To characterize photolytic conditions in the chamber, irradiance spectra were collected in the wavelength range of $180-600 \mathrm{~nm}$ at $\sim 0.8 \mathrm{~nm}$ resolution by a custom-built spectroradiometer, as shown in Fig. S1 in the Supplement (Petropavlovskikh et al., 2007). Photolysis frequencies were calculated based on the measured downwelling spectral actinic fluxes. The computed photolysis rate of $\mathrm{NO}_{2}\left(J_{\mathrm{NO}_{2}} \sim\right.$ $1.27 \times 10^{-3} \mathrm{~s}^{-1}$ ) agrees within $3 \%$ with that measured by photolyzing $18.6 \mathrm{ppb} \mathrm{NO}_{2}$ in the chamber and monitoring the NO production rate. The chamber is equipped with a standard set of measurements, including an integrated temperature and humidity probe (model 50U, VAISALA, CO) and a Magnehelic differential pressure indicating transmitter (model 60511, Dwyer Instruments, IN). The chamber temperature is controlled at $295 \mathrm{~K}$ by the building's air conditioning system and increases to 305-306 K under maximum irradiation conditions. The relative humidity of the chamber air is below $10 \%$ under dry conditions (the remaining water vapor is generated from methane combustion during the air purification process) and can be varied in the range of $\sim 10-50 \%$ by flowing a portion of the purified dry flushing air into the chamber through a temperature-controlled water reservoir. Typical temperature and relative humidity profiles across the chamber under maximum irradiation conditions are given in Fig. S1 in the Supplement. The chamber internal pressure is maintained slightly above the ambient pressure to minimize the enclosure air contamination via penetration through the Teflon film.

Prior to each experiment, the chamber was flushed with purified dry air from an ultra high purity zero air generator (model 737, Aadco Instruments, $\mathrm{OH}$ ) for $>12 \mathrm{~h}$ until ozone and $\mathrm{NO}_{x}$ levels were below $1 \mathrm{ppb}$. During the operation of the steady-state continuous flow mode, the chamber was constantly flushed with purified dry air at $40 \mathrm{~L} \mathrm{~min}^{-1}$, which gives an average chamber residence time of $4.17 \mathrm{~h}$. The incoming and outgoing flows were balanced by a feedback control system that maintains a constant internal pressure of 1.2-4.9 $\times 10^{-4}$ atm above the ambient. The chamber is actively mixed by the turbulence created by the $40 \mathrm{~L} \mathrm{~min}^{-1}$ flushing air. The characteristic mixing time is defined as the time it takes for the measurement signal of a tracer compound (e.g., $\mathrm{CO}_{2}$ and $\mathrm{NO}$ ) to stabilize following a pulse injection. The average mixing time in the NCAR chamber was determined to be $\sim 9 \mathrm{~min}$, which is $\sim 4 \%$ of the residence time. Under such conditions, the gas- and particle-phase composition in the outflow can be assumed identical to that in the well-mixed core of the chamber.

To mimic daytime photochemistry in the continuous flow mode, steady-state $\mathrm{OH}$ mixing ratio was created by photolyzing hydrogen peroxide $\left(\mathrm{H}_{2} \mathrm{O}_{2}\right)$ vapor that was continuously flowing into the chamber $\left(\mathrm{H}_{2} \mathrm{O}_{2}+h v \rightarrow 2 \mathrm{OH}, J_{\mathrm{H}_{2} \mathrm{O}_{2}} \sim\right.$ $4.33 \times 10^{-7} \mathrm{~s}^{-1}$ ). Specifically, a $20 \mathrm{~mL}$ syringe (NORMJECT, Henke-Sass Wolf, MA) held on a syringe pump (model 100, KD Scientific, MA) kept at $\sim 4^{\circ} \mathrm{C}$ was used to deliver $\mathrm{H}_{2} \mathrm{O}_{2}$ solution (1-30 wt \%, Sigma Aldrich, $\mathrm{MO}$ ) into a glass bulb that was gently warmed at $\sim 32{ }^{\circ} \mathrm{C}$. The liquid delivery rate was sufficiently slow $\left(100-300 \mu \mathrm{L} \mathrm{min}^{-1}\right)$ that all the $\mathrm{H}_{2} \mathrm{O}_{2}$ vapor was released into the glass bulb through evaporation of a small droplet hanging on the needle tip. An air stream $\left(5 \mathrm{~L} \mathrm{~min}^{-1}\right)$ swept the $\mathrm{H}_{2} \mathrm{O}_{2}$ vapor into the chamber, resulting in an $\mathrm{H}_{2} \mathrm{O}_{2}$ mixing ratio in the range of $600 \mathrm{ppb}$ to $16.22 \mathrm{ppm}$ in the injection flow as a function of the concentration of $\mathrm{H}_{2} \mathrm{O}_{2}$ aqueous solution used. A spreadsheet (Table $\mathrm{S} 2$ ) for calculating the inflow $\mathrm{H}_{2} \mathrm{O}_{2}$ mixing ratio using the above input method is provided in the Supplement. As $\mathrm{H}_{2} \mathrm{O}_{2}$ laden air was continuously entering the chamber, it took approximately three turnover times $(\sim 12.5 \mathrm{~h})$ for the desired $\mathrm{H}_{2} \mathrm{O}_{2}$ vapor mixing ratio to reach steady state in the chamber. The $\mathrm{H}_{2} \mathrm{O}_{2}$ vapor concentration in the chamber, though not measured, can be estimated from the steady-state $\mathrm{OH}$ mixing ratio derived from the observed exponential decay of a given parent hydrocarbon. Constant $\mathrm{NO}$ injection flow was achieved by diluting the gas flow from a concentrated $\mathrm{NO}$ cylinder $\left(\mathrm{NO}=133.16 \mathrm{ppm}\right.$, balance $\left.\mathrm{N}_{2}\right)$ to a desired mixing ratio (0.1-100 ppb) using a set of mass flow controllers (Tylan FC260 and FC262, Mykrolis Corp., MA). The lowest steady-state NO level that can be achieved in the chamber is around $30 \mathrm{ppt}$ (unpublished, NCAR). Note that for experiments performed in the absence of any VOC precursor, $\mathrm{H}_{2} \mathrm{O}_{2}$ and $\mathrm{NO}$ were the only two species that were continuously input into the chamber for the establishment of a combination of different photochemical conditions as denoted by the $\mathrm{O}_{3}$ and $\mathrm{NO}_{x}$ measurements. For the isoprene photooxidation experiments, an isoprene standard $\left(\mathrm{C}_{5} \mathrm{H}_{8}=531 \mathrm{ppm}\right.$, balance $\mathrm{N}_{2}$ ) was constantly injected into the chamber and diluted with the flushing air to achieve an inflow concentration of $\sim 20 \mathrm{ppb}$.

To mimic the nighttime chemistry in the continuous flow mode, steady-state $\mathrm{NO}_{3}$ mixing ratio was created by constantly flowing diluted $\mathrm{O}_{3}$ and $\mathrm{NO}$ air into the chamber $\left(\mathrm{NO}+\mathrm{O}_{3} \rightarrow \mathrm{NO}_{2}+\mathrm{O}_{2} ; \mathrm{NO}_{2}+\mathrm{O}_{3} \rightarrow \mathrm{NO}_{3}+\mathrm{O}_{2}\right)$. The $\mathrm{NO}$ source can be replaced by $\mathrm{NO}_{2}$, although the absolute absence of NO does not necessarily represent the actual atmospheric conditions. $\mathrm{O}_{3}$ was produced by photolyzing $\mathrm{O}_{2}$ in air at $185 \mathrm{~nm}$ using a mercury Pen-Ray lamp (UVP LLC, CA). Ozone concentration in the injection flow can 
be controlled from 3.5 to $457 \mathrm{ppb}$ automatically by adjusting the mercury lamp duty cycle. To study the $\mathrm{RO}_{2}+\mathrm{HO}_{2}$ pathway, formaldehyde $\left(\mathrm{CH}_{2} \mathrm{O}\right)$ was input into the chamber along with $\mathrm{NO}$ and $\mathrm{O}_{3}$ to initiate $\mathrm{HO}_{2}$ production $\left(\mathrm{NO}_{3}+\mathrm{CH}_{2} \mathrm{O}+\mathrm{O}_{2} \rightarrow \mathrm{HNO}_{3}+\mathrm{HO}_{2}+\mathrm{CO}\right)$. Formaldehyde aqueous solution ( $37 \mathrm{wt} \%$, Sigma Aldrich, MO) was diluted with ultrapure water (Milli-Q, Merck Millipore, MA) to $0.2-1.0 \mathrm{wt} \%$ and continuously input into the chamber using the same method used for $\mathrm{H}_{2} \mathrm{O}_{2}$ input described above. It is worth noting that the formaldehyde aqueous solution contains $10-15 \%$ methanol as stabilizer to prevent polymerization. The presence of methanol in the chamber does not significantly impact the nocturnal chemistry as it consumes $\mathrm{OH}$ and $\mathrm{NO}_{3}$ radicals to generate formaldehyde and additional $\mathrm{HO}_{2}\left(\mathrm{CH}_{3} \mathrm{OH}+\mathrm{NO}_{3} \rightarrow \mathrm{HNO}_{3}+\mathrm{CH}_{2} \mathrm{O}+\right.$ $\mathrm{HO}_{2}, \mathrm{CH}_{3} \mathrm{OH}+\mathrm{OH} \rightarrow \mathrm{H}_{2} \mathrm{O}+\mathrm{CH}_{2} \mathrm{O}+\mathrm{HO}_{2}$ ) (Atkinson et al., 2006). The use of formaldehyde as an $\mathrm{HO}_{2}$ source mimics closely the atmospheric nighttime conditions in forest environments (Schwantes et al., 2015). To study the $\mathrm{NO}_{3}$ initiated oxidation of isoprene, an injection flow of diluted isoprene $(\sim 10 \mathrm{ppb})$ was achieved using the procedure described above.

\subsection{Analytical measurements}

A suite of instruments was used to monitor gas-phase concentrations in the chamber outflow. $\mathrm{O}_{3}$ was monitored by absorption spectroscopy with $0.5 \mathrm{ppb}$ detection limit (model 49, Thermo Scientific, $\mathrm{CO}$ ). The $\mathrm{O}_{3}$ monitor was calibrated using an Ozone Primary Standard in the range of 0-200 ppb (model 49i-PS, Thermo Scientific, CO). The $\mathrm{O}_{3}$ monitor used for chamber experiments was periodically checked with the primary standard and was shown to be stable over long periods of time (less than $1 \mathrm{ppb}$ drift in over 1 year). NO was monitored by chemiluminescence with $0.5 \mathrm{ppb}$ detection limit (model CLD 88Y, Eco Physics, MI). Zero-point and span calibrations of the $\mathrm{NO}_{x}$ monitor were performed prior to each experiment by supplying the instrument with pure $\mathrm{N}_{2}$ gas and diluted NO, respectively. Multi-point calibration was performed on a weekly basis and has shown a good stability and linearity in the $\mathrm{NO}$ measurement ranging from 1 to $200 \mathrm{ppb}$. $\mathrm{NO}_{x}\left(\mathrm{NO}+\mathrm{NO}_{2}\right)$ measurements were performed using a photolytic converter that selectively converts $\mathrm{NO}_{2}$ to $\mathrm{NO}$ upstream of the photo-multiplier tube in the CLD 88Y NO monitor. This converter uses two opposing arrays of UV LEDs shining into a cylindrical quartz mixing tube to achieve approximately $50 \%$ conversion of $\mathrm{NO}_{2}$ to NO per second. The total efficiency for the equipment described here is approximately $70 \%$ as determined by measuring calibrated $\mathrm{NO}_{2}$ standards. The sample path always includes the photolytic converter, and typical experiments cycle the power for the LED lights to switch between measuring $\mathrm{NO}$ (lights off) and $\mathrm{NO}_{x}$ (lights on). $\mathrm{NO}_{2}$ concentrations were then determined by subtracting the NO from the adjacent $\mathrm{NO}_{x}$ measurements.
A customized proton transfer reaction quadrupole mass spectrometer (PTR-Q-MS) was used to measure volatile organic compounds including isoprene $\left(\mathrm{C}_{5} \mathrm{H}_{8}\right)$, MACR $\left(\mathrm{C}_{4} \mathrm{H}_{6} \mathrm{O}\right)$, and MVK $\left(\mathrm{C}_{4} \mathrm{H}_{6} \mathrm{O}\right)$. The instrument was operated at $2.3 \mathrm{mbar}$ drift pressure and $560 \mathrm{~V}$ drift voltage. Measurements reported here were obtained at a sampling rate of $10 \mathrm{~Hz}$. In positive-mode operation, a given analyte [M] undergoes proton transfer reaction, producing an ion of the form $[\mathrm{M}+\mathrm{H}]^{+}$; that is, isoprene is detected as ion $\mathrm{C}_{5} \mathrm{H}_{9}^{+}$ $(m / z$ 69) and MACR and MVK are both detected as ion $\mathrm{C}_{4} \mathrm{H}_{7} \mathrm{O}^{+}(\mathrm{m} / z$ 71). The instrument background was collected by sampling the chamber air for at least $30 \mathrm{~min}$ prior to each experiment. Measured ion intensities for isoprene $\left(\mathrm{C}_{5} \mathrm{H}_{9}^{+}, m / z\right.$ 69) and MACR and MVK $\left(\mathrm{C}_{4} \mathrm{H}_{7} \mathrm{O}^{+}, m / z\right.$ 71) were calculated as the signal of each ion (counts per seconds) normalized to the total ion signal of $\mathrm{H}_{3} \mathrm{O}^{+}$. The instrument sensitivities towards isoprene, MACR, and MVK were calibrated with a mixture of diluted gas standards. The instrument sensitivity towards MACR is identical to that of MVK and, as a result, the sum of MACR and MVK concentration in the sampling air can be calculated by applying one calibration factor to the measured $\mathrm{C}_{4} \mathrm{H}_{7} \mathrm{O}^{+}(m / z, 71)$ signal intensity. Since artifacts in the measured $\mathrm{C}_{4} \mathrm{H}_{7} \mathrm{O}^{+}$signal can be produced through thermal decomposition of isoprene oxidation products, such as the peroxides, nitrates, and epoxides, on contact with hot metal surface (Liu et al., 2013; Nguyen et al., 2014b; Rivera-Rios et al., 2014), a cold-trap system was used to avoid bias in the interpretation of the PTR-QMS data. Specifically, a $1 \mathrm{~m}$ section of Teflon tubing was submerged in a low-temperature ethanol bath $\left(-40 \pm 2{ }^{\circ} \mathrm{C}\right)$ that could trap oxidized products less volatile than the authentic MACR and MVK standards after steady state was established in the chamber. The quantification of the sum of MACR and MVK was then based on the PTR-Q-MS measured $\mathrm{C}_{4} \mathrm{H}_{7} \mathrm{O}^{+}(m / z 71)$ signal downstream of the cold trap.

\section{Kinetic modeling}

Reaction kinetics and mechanisms for the gas-phase photochemistry were extracted from the Master Chemical Mechanism (MCMv3.3.1, accessible at http://mcm.leeds.ac.uk/ MCM/, last access: 4 January 2018). The inorganic reaction scheme includes 21 species and 48 reactions; the isoprene oxidation system includes 611 species and 1974 reactions. The kinetic schemes were implemented in MATLAB (Mathworks) to simulate the temporal profile of a given compound $i$ in the chamber operated in the steady-state continuous flow mode:

$$
\frac{\mathrm{d} C_{i}}{\mathrm{~d} t} \cdot \tau=C_{i, 0}+P_{i}-C_{i}-\sum k_{i} \cdot \tau \cdot C_{i},
$$

where $C_{i}\left(\right.$ molec $\left.\mathrm{cm}^{-3}\right)$ is the gas-phase concentration of compound $i$ in the well-mixed core of the chamber; $C_{i, 0}$ $\left(\right.$ molec $\left.\mathrm{cm}^{-3}\right)$ is the initial gas-phase concentration of com- 
pound $i$ in the injection flow; $k_{i}\left(\mathrm{~s}^{-1}\right)$ is the pseudo-firstorder rate coefficient for a chemical reaction that consumes compound $i ; \tau(\mathrm{s})$ is the chamber mean residence time and can be calculated as the total chamber volume divided by the incoming and outgoing flow rate; and $P_{i}\left(\right.$ molec $\left.\mathrm{cm}^{-3}\right)$ is the increment in the concentration of compound $i$ through chemical production during one residence time. Note that two terms are neglected in Eq. (1), i.e., organic vapor condensation onto particles and deposition on the chamber wall. This is a reasonable simplification here due to the relatively high volatility ( $\geq 10^{-1} \mathrm{~atm}$ ) of compounds studied (Zhang et al., 2015b; Krechmer et al., 2016; Huang et al., 2018). Incorporation of these two terms into Eq. (1) is feasible given the vapor pressure of compound $i$, suspended particle size distribution, gas-particle and gas-wall partitioning coefficient, accommodation coefficients of compound $i$ on particles and walls, and the effective absorbing organic masses on the wall (Zhang et al., 2014a, 2015b; Huang et al., 2016; McVay et al., 2016; Nah et al., 2016).

Model simulations used for comparison with chamber measurements were initialized using experimental conditions summarized in Table S1 in the Supplement. Model input parameters for all simulations include temperature $(295 \mathrm{~K}$ at dark and $306 \mathrm{~K}$ under irradiation), local pressure $(8.6 \times$ $10^{4} \mathrm{~Pa}$ ), relative humidity $(8 \%$ at dark and $5 \%$ under irradiation), light intensity $\left(\mathrm{N}_{\mathrm{NO}_{2}}=1.27 \times 10^{-3} \mathrm{~s}^{-1}\right.$ under irradiation and 0 at dark), chamber mean residence time $(4.17 \mathrm{~h})$, and input mixing ratios of $\mathrm{H}_{2} \mathrm{O}_{2}(0.11-16.2 \mathrm{ppm}$ for photolytic experiments), $\mathrm{NO}(0.1-100 \mathrm{ppb}$ for photolytic experiments and 10-20 ppb for dark experiments), $\mathrm{O}_{3}(22-225 \mathrm{ppb}$ for dark experiments), $\mathrm{HCHO}(0-600 \mathrm{ppb}$ for dark experiments), and isoprene (19.9 ppb for photolytic experiments and $10.2 \mathrm{ppb}$ for dark experiments). The model was propagated numerically for $25 \mathrm{~h}$ duration for each experiment.

\section{Results and discussions}

\subsection{Optimal operating conditions for daytime photochemistry}

Figure 1 shows the model-predicted steady-state mixing ratios of $\mathrm{OH}, \mathrm{HO}_{2}, \mathrm{NO}_{3}, \mathrm{NO}, \mathrm{NO}_{2}$, and $\mathrm{O}_{3}$ in the chamber after $20 \mathrm{~h}$ of photochemical reactions as a function of the $\mathrm{H}_{2} \mathrm{O}_{2}$ and $\mathrm{NO}$ concentrations in the continuous injection flow. Six blank chamber experiments were compared with simulations. In general, the model captures the evolution patterns of $\mathrm{NO}_{x}$ and $\mathrm{O}_{3}$ well. The predicted mixing ratios of $\mathrm{NO}, \mathrm{NO}_{2}$, and $\mathrm{O}_{3}$ agree within 69,11 , and $33 \%$, respectively, with the measurements (see Table S1 and Fig. S2 in the Supplement). The relatively large NO uncertainties originate from the measurements that were performed close to the instrument detection limit $(0.5 \mathrm{ppb})$.

Simulated steady-state mixing ratios of $\mathrm{OH}$ radicals $\left([\mathrm{OH}]_{\mathrm{ss}}\right)$ range from $\sim 5 \times 10^{5}$ to $\sim 4 \times 10^{6} \mathrm{molec} \mathrm{cm}^{-3}$, which over $\sim 4 \mathrm{~h}$ chamber residence time would be roughly equivalent to $\sim 1$ to $\sim 8 \mathrm{~h}$ of atmospheric $\mathrm{OH}$ exposure $\left(1 \times 10^{6}\right.$ molec cm $\left.^{-3}\right)$. As expected, $[\mathrm{OH}]_{\mathrm{ss}}$ increases with increasing $\mathrm{NO}$ influxes due to the enhanced $\mathrm{NO}_{x} / \mathrm{O}_{3}$ cycling but decreases with increasing $\mathrm{H}_{2} \mathrm{O}_{2}$ influxes due to the overwhelming reaction $\mathrm{OH}+\mathrm{H}_{2} \mathrm{O}_{2} \rightarrow \mathrm{H}_{2} \mathrm{O}+\mathrm{HO}_{2}$. As a consequence, the steady-state mixing ratios of $\mathrm{HO}_{2}$ radicals $\left(\left[\mathrm{HO}_{2}\right]_{\mathrm{ss}}\right)$ reach up to $\sim 7 \times 10^{9} \mathrm{molec} \mathrm{cm}^{-3}$ when $16.2 \mathrm{ppm}$ $\mathrm{H}_{2} \mathrm{O}_{2}$ is continuously injected into the chamber. If $110 \mathrm{ppb}$ $\mathrm{H}_{2} \mathrm{O}_{2}$ is used instead, the resulting $\left[\mathrm{HO}_{2}\right]_{\mathrm{ss}}$ levels fall close to the ambient range $\left(\sim 10^{8}\right.$ molec $\left.\mathrm{cm}^{-3}\right)$.

Simulated steady-state NO mixing ratios in the chamber range from $\sim 2 \mathrm{ppt}$ to $\sim 0.9 \mathrm{ppb}$ from combinations of $0.1-$ $20 \mathrm{ppb} \mathrm{NO}$ and $0.11-16.22 \mathrm{ppm} \mathrm{H}_{2} \mathrm{O}_{2}$ in the injection flow. The ratio of inflow NO concentration to the steady-state NO concentration in the chamber ranges from 5 to 93 , demonstrating the importance of chemical removal in controlling the overall steady-state NO levels. $\mathrm{O}_{3}$ accumulation is an inevitable consequence under photolytic conditions and, for example, the presence of $10 \mathrm{ppb} \mathrm{O}_{3}$ leads to the chemical removal term $\left(k_{\mathrm{O}_{3}+\mathrm{NO}} \cdot\left[\mathrm{O}_{3}\right] \cdot \tau\right)$ in Eq. (1) that reduces the steady-state NO concentration by a factor of 60 . It is worth noting that under all simulated conditions in the continuous flow mode, $\mathrm{O}_{3}(\sim 1-126 \mathrm{ppb})$ coexists with $\mathrm{NO}(\sim 0.002-$ $0.9 \mathrm{ppb})$. This particular chemical scenario, which is impossible to achieve in batch-mode reactors due to prompt conversion of $\mathrm{NO}$ to $\mathrm{NO}_{2}$, could then be used to mimic ambient ozonolysis chemistry, for example, in forest regions that frequently encounter polluted air masses from nearby urban areas. The steady-state mixing ratios of $\mathrm{NO}_{2}\left(\left[\mathrm{NO}_{2}\right]_{\mathrm{ss}}\right)$ exhibit a strong linear correlation with NO influxes. The use of less than $20 \mathrm{ppb} \mathrm{NO}$ in the injection flow results in a few to tens of ppb $\left[\mathrm{NO}_{2}\right]_{\mathrm{ss}}$, which is higher than the range typically found in the ambient. The potential "quenching" effect of $\mathrm{NO}_{2}$ on $\mathrm{RO}_{2}$ radicals through reversible termolecular reactions is discussed shortly.

In the so-called "high- $\mathrm{NO}_{x}$ " chamber experiments, the $\mathrm{NO}_{3}$ radical is an unavoidable side-product when black lights are used as a representative of the solar radiation in mimicking the daytime photochemistry in the troposphere. The photolysis of $\mathrm{NO}_{3}$, although its primary sink in the atmosphere, proceeds rather slowly $\left(J_{\mathrm{NO}_{3}} \sim 1.8 \times 10^{-3} \mathrm{~s}^{-1}\right)$ under the present chamber photolytic conditions, thereby leading to a significant accumulation of $\mathrm{NO}_{3}$ radicals $\left(7.9 \times 10^{4}-2.8 \times\right.$ $10^{8}$ molec $\mathrm{cm}^{-3}$ ) at steady state. The simulated $\mathrm{NO}_{3} / \mathrm{OH}$ ratio dictates the extent to which the $\mathrm{NO}_{3}$ (nighttime) chemistry competes with the $\mathrm{OH}$-initiated (daytime) photochemistry. For compounds that are highly reactive towards $\mathrm{NO}_{3}$ such as isoprene, $\mathrm{NO}_{3}$-initiated oxidation accounts for up to $\sim 60 \%$ of the overall isoprene degradation pathways at the highest $\mathrm{NO}_{3} / \mathrm{OH}$ ratio $(\sim 255)$ simulated. Low concentrations of $\mathrm{NO}(<20 \mathrm{ppb})$ and $\mathrm{H}_{2} \mathrm{O}_{2}(<2 \mathrm{ppm})$ in the injection flow are therefore necessary to limit the interferences of $\mathrm{NO}_{3}$-initiated chemistry. Again, taking isoprene as an example, the $\mathrm{NO}_{3}$ oxidation pathway contributes less than $0.1 \%$ 

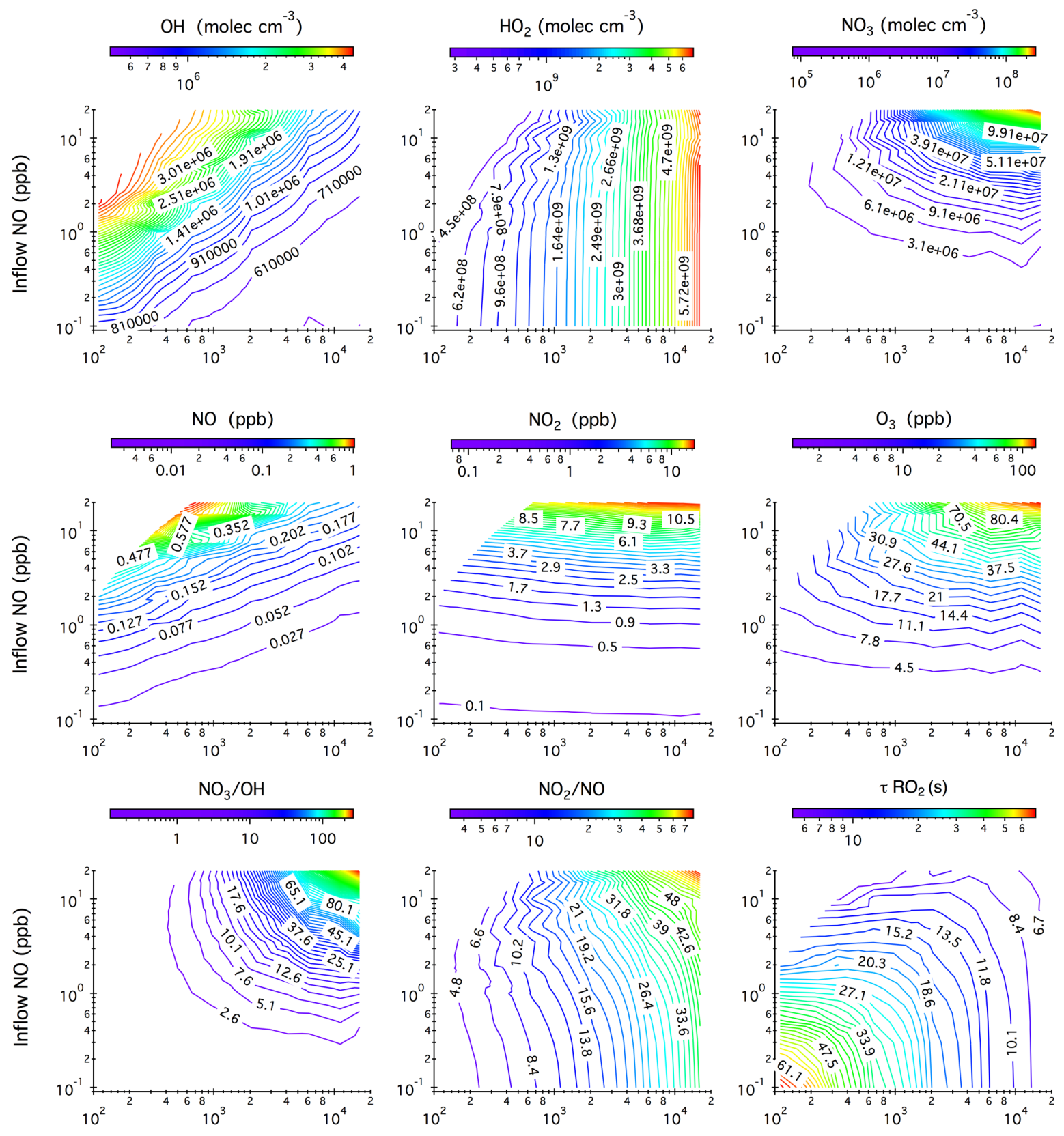

Inflow $\mathrm{H}_{2} \mathrm{O}_{2}(\mathrm{ppb})$

Inflow $\mathrm{H}_{2} \mathrm{O}_{2}(\mathrm{ppb})$
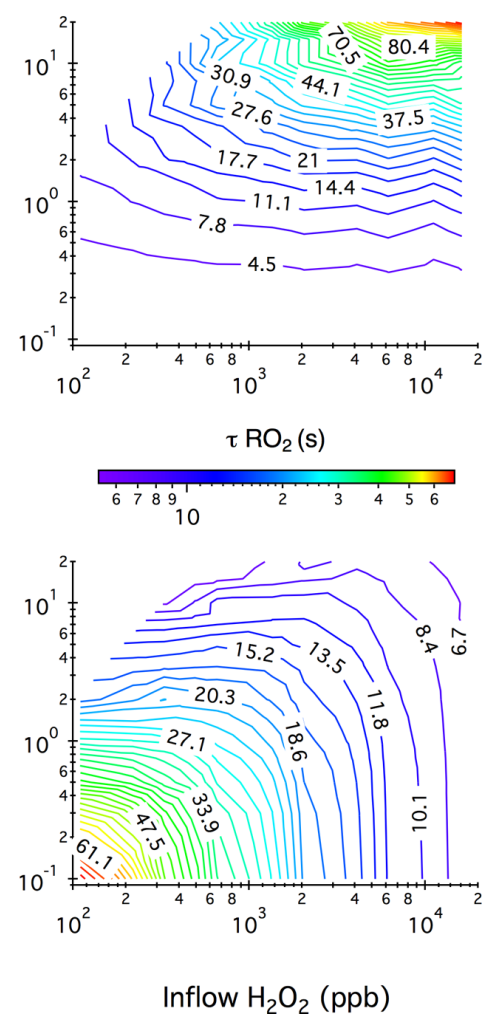

Figure 1. Contour plots showing the model-predicted steady-state mixing ratios of $\mathrm{OH}, \mathrm{HO}_{2}, \mathrm{NO}_{3}, \mathrm{NO} \mathrm{NO}_{2}$, and $\mathrm{O}_{3}$ after $20 \mathrm{~h}$ of photochemical reactions in the chamber as a function of the concentrations of $\mathrm{H}_{2} \mathrm{O}_{2}$ and $\mathrm{NO}$ in the continuous injection flow. Also given here are the simulated $\mathrm{NO}_{3}$ to $\mathrm{OH}$ ratio, $\mathrm{NO}_{2}$ to $\mathrm{NO}$ ratio, and the lifetime of an $\mathrm{RO}_{2}$ radical $\left(\tau_{\mathrm{RO}_{2}}\right)$ with respect to reactions with $\mathrm{NO}$ and $\mathrm{HO}$. Note that the ripples on the contour lines originate from the limited simulation datasets that are used to generate iso-response values.

of the overall isoprene degradation kinetics at the lowest $\mathrm{NO}_{3} / \mathrm{OH}$ ratio $(\sim 0.13)$ simulated here.

Also given in Fig. 1 is the calculated lifetime $\left(\tau_{\mathrm{RO}_{2}}\right)$ of an $\mathrm{RO}_{2}$ radical with respect to reactions with $\mathrm{NO}$ and $\mathrm{HO}_{2}$ at $306 \mathrm{~K}$. In most batch-mode chamber experiments, $\tau_{\mathrm{RO}_{2}}$ of only several seconds or less can be achieved due to the presence of tens to hundreds of ppb levels of $\mathrm{NO}$ and $\mathrm{HO}_{2}$.
Here $\tau_{\mathrm{RO}_{2}}$ could extend to $60 \mathrm{~s}$ or even longer with the continuous input of low mixing ratios of $\mathrm{H}_{2} \mathrm{O}_{2}(\leq 110 \mathrm{ppb})$ and $\mathrm{NO}(\leq 0.2 \mathrm{ppb})$. Note that the presence of tens of $\mathrm{ppb}$ $\mathrm{NO}_{2}$ in the chamber might impose a "quenching" effect on the steady-state $\mathrm{RO}_{2}$ level through rapid reversible reactions $\left(\mathrm{RO}_{2}+\mathrm{NO}_{2}+\mathrm{M} \leftrightarrow \mathrm{RO}_{2} \mathrm{NO}_{2}+\mathrm{M}\right)$. We evaluate this potential "quenching effect" using ethyl peroxy radical $\left(\mathrm{C}_{2} \mathrm{H}_{5} \mathrm{O}_{2}\right)$ 

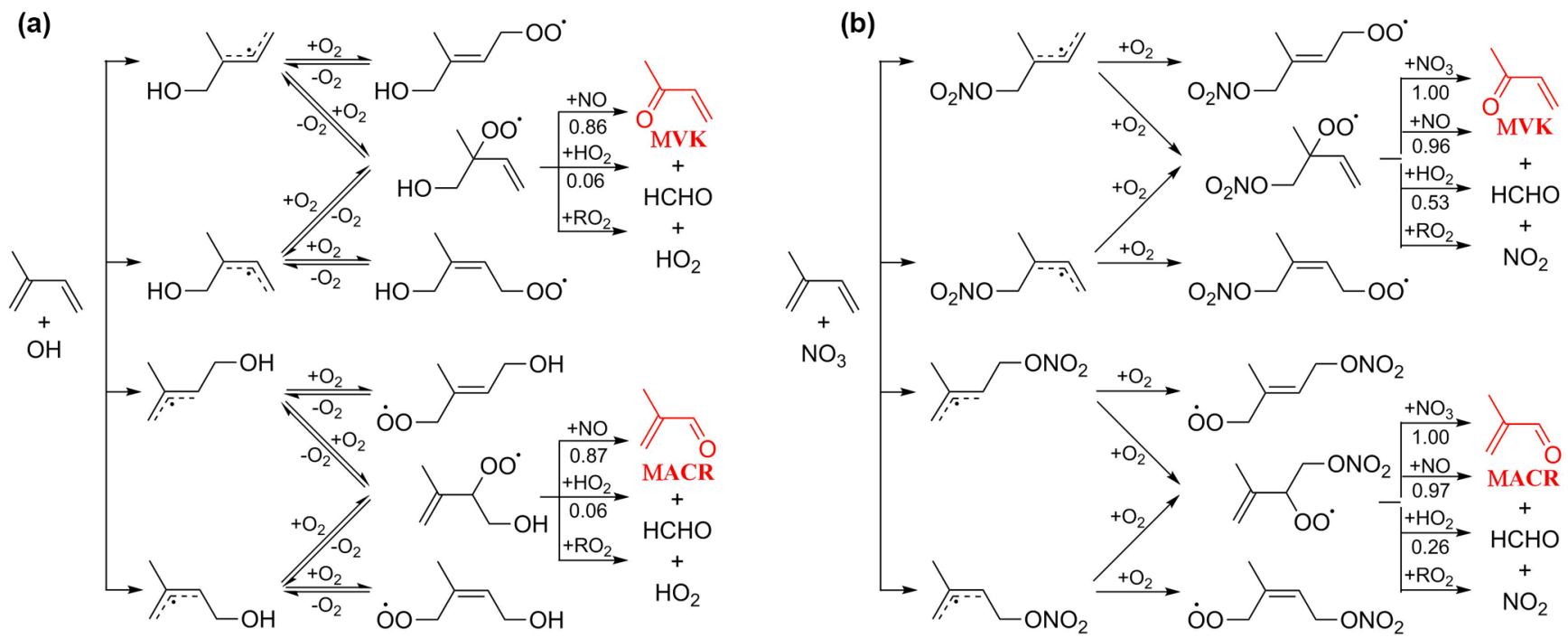

Figure 2. Representative mechanism for (a) $\mathrm{OH}-$ and (b) $\mathrm{NO}_{3}$-initiated oxidation of isoprene that leads to the formation of MACR and MVK.

generated from $\mathrm{OH}$ oxidation of ethane as an example. Simulations shown in Fig. S3 in the Supplement reveal that incorporation of the $\mathrm{C}_{2} \mathrm{H}_{5} \mathrm{O}_{2}+\mathrm{NO}_{2}+\mathrm{M} \leftrightarrow \mathrm{C}_{2} \mathrm{H}_{5} \mathrm{O}_{2} \mathrm{NO}_{2}+\mathrm{M}$ reaction into the mechanism in the presence of $\sim 1-80 \mathrm{ppb}$ $\mathrm{NO}_{2}$ does not notably change the behavior of $\mathrm{C}_{2} \mathrm{H}_{5} \mathrm{O}_{2}$ radical. One exception is the peroxyacyl radical, which combines with $\mathrm{NO}_{2}$ yielding peroxyacyl nitrate. For example, under $0.1-16 \mathrm{ppb}\left[\mathrm{NO}_{2}\right]_{\mathrm{ss}}$ as displayed in Fig. 1, we calculate that the time needed for peroxyacetyl radical $\left(\mathrm{CH}_{3} \mathrm{C}(\mathrm{O}) \mathrm{O}_{2}\right)$ to reach equilibrium with peroxyacetyl nitrate $\left(\mathrm{CH}_{3} \mathrm{C}(\mathrm{O}) \mathrm{O}_{2}+\mathrm{NO}_{2}+\mathrm{M} \leftrightarrow \mathrm{CH}_{3} \mathrm{C}(\mathrm{O}) \mathrm{O}_{2} \mathrm{NO}_{2}+\mathrm{M}\right)$ ranges from $\sim 1$ to $\sim 10 \mathrm{~s}$, suggesting that the lifetime of peroxyacyl radicals is ultimately controlled by $\mathrm{NO}_{2}$ instead of $\mathrm{NO} / \mathrm{HO}_{2}$ in the reaction system and, consequently, peroxyacyl radicals are not expected to be long-lived in the current chamber configuration.

We further compare the photochemical oxidation environment created here with the "intermediate-NO" conditions achieved by other chambers that employed the experimental approaches introduced earlier. In terms of the oxidizing power, all approaches are capable of maintaining an atmospheric relevant $\mathrm{OH}$ level $\left(\sim 10^{6}\right.$ molec $\left.\mathrm{cm}^{-3}\right)$ except the "slow chemistry" scenario that limits the photolysis rate of the $\mathrm{OH}$ precursor and results in an average $\mathrm{OH}$ mixing ratio of $\sim 10^{5}$ molec $\mathrm{cm}^{-3}$ (Crounse et al., 2012; Teng et al., 2017). At comparable $\mathrm{OH}$ levels, the overall atmospheric $\mathrm{OH}$ exposure achieved in the flow tube reactor is rather limited due to the short residence time (e.g., $\sim 80 \mathrm{~s}$ in the PAM reactor). In terms of the $\mathrm{NO}_{x}$ level, precisely controlled steadystate NO concentration can be achieved for an indefinite time period by operating chambers in the continuously mixed flow mode. However, $\mathrm{NO}_{2}$ accumulates during the continuous oxidation process and the resulting $\mathrm{NO}_{2} / \mathrm{NO}$ ratio can be as much as an order of magnitude higher than that achieved in the static outdoor chambers.

\subsection{Application to $\mathrm{OH}$-initiated oxidation of isoprene}

MACR and MVK are major first-generation products from the $\mathrm{OH}$-initiated oxidation of isoprene in the presence of $\mathrm{NO}$ (Wennberg et al., 2018). They are produced from the decomposition of $\beta$-ISOPO alkoxy radicals that are primarily formed from the reaction of $\beta$-ISOPOO peroxy radicals ( $\beta$ $1-\mathrm{OH}-2-\mathrm{OO}$ and $\beta$-4-OH-3-OO) with NO; see mechanisms displayed in Fig. 2a. Reactions of $\beta$-ISOPOO peroxy radicals with $\mathrm{HO}_{2}$ and $\mathrm{RO}_{2}$ also partially yield $\beta$-ISOPO alkoxy radicals that ultimately lead to MACR and MVK, although these pathways are considered to be minor in the presence of hundreds to thousands of ppt NO in the atmosphere. The molar yields determined from previous studies range from 30 to $35 \%$ for MVK and from 20 to $25 \%$ for MACR under highNO conditions (NO > $60 \mathrm{ppb}$ ) (Tuazon and Atkinson, 1990; Paulson and Seinfeld, 1992; Miyoshi et al., 1994; Ruppert and Becker, 2000; Sprengnether et al., 2002; Galloway et al., 2011; Liu et al., 2013). It has been recently shown that the six hydroxyl peroxy radicals (ISOPOO) produced from the initial $\mathrm{OH}$ addition to the double bonds of isoprene undergo rapid interconversion by removal or addition of $\mathrm{O}_{2}$ that competes with bimolecular reactions under atmospherically relevant NO levels (Peeters et al., 2014; Teng et al., 2017). As a result, the distribution of ISOPOO radical isomers and their subsequent reaction products varies with their lifetimes with respect to bimolecular reactions. In the presence of hundreds of ppb $\mathrm{NO}$ as done by most previous experimental studies, the reaction of ISOPOO radicals with NO dominates over their interconversion, and the production of $\beta$-ISOPOO peroxy radical is less favored, leading the experiments to under- 
estimate the MACR and MVK yields typically obtained in ambient conditions. Measurements by Karl et al. (2006) and Liu et al. (2013) conducted at NO concentrations comparable to the moderately polluted urban environment $(\sim 0.2 \mathrm{ppb}$ in Karl et al. and $\sim 1 \mathrm{ppb}$ in Liu et al.) found higher MACR ( $\sim 27 \%$ in Karl et al. and $\sim 31.8 \%$ in Liu et al.) and MVK ( $\sim 41 \%$ in Karl et al. and $\sim 44.5 \%$ in Liu et al.) yields than other studies.

Here we perform a steady-state continuous-mode experiment to measure the production of MACR and MVK from the $\mathrm{OH}$-initiated oxidation of isoprene in the presence of $\sim 0.45 \mathrm{ppb}$ NO. Figure 3 shows the observed and simulated temporal profiles of $\mathrm{NO}_{x}, \mathrm{O}_{3}, \mathrm{C}_{5} \mathrm{H}_{8}$, and $\mathrm{C}_{4} \mathrm{H}_{6} \mathrm{O}$ over $24 \mathrm{~h}$ photooxidation of isoprene. In this experiment, $\mathrm{C}_{5} \mathrm{H}_{8}, \mathrm{H}_{2} \mathrm{O}_{2}$, and $\mathrm{NO}$ were continuously fed into the chamber, with constant inflow concentrations of $19.9,600$, and $19 \mathrm{ppb}$, respectively. An outgoing flow at $40 \mathrm{~L} \mathrm{~min}^{-1}$ continuously withdrew air from the chamber to balance the pressure. After approaching steady state, the sampling tube was submerged into a low-temperature ethanol bath $\left(-40 \pm 2{ }^{\circ} \mathrm{C}\right)$ to trap oxidized products that would otherwise undergo thermal decomposition introducing interferences in the $\mathrm{C}_{4} \mathrm{H}_{7} \mathrm{O}^{+}(\mathrm{m} / z$ 71) signal. The measured concentrations of $\mathrm{C}_{5} \mathrm{H}_{8}$ and $\mathrm{C}_{4} \mathrm{H}_{6} \mathrm{O}$ upon cold trapping agree within 2.8 and $4.6 \%$ uncertainties with the model simulations (see Fig. $3 \mathrm{c}$ and d).

To calculate the total molar yield $\left(Y_{\mathrm{C}_{4} \mathrm{H}_{6} \mathrm{O}}\right)$ of MACR and MVK, two reactions are considered:

$\mathrm{C}_{5} \mathrm{H}_{8}+\mathrm{OH} \stackrel{k_{1}}{\longrightarrow} Y_{\mathrm{C}_{4} \mathrm{H}_{6} \mathrm{O}} \cdot \mathrm{C}_{4} \mathrm{H}_{6} \mathrm{O}+$ products,

$\mathrm{C}_{4} \mathrm{H}_{6} \mathrm{O}+\mathrm{OH} \stackrel{k_{2}}{\longrightarrow}$ products,

where $k_{1}$ is the rate constant for $\mathrm{OH}$ reaction with isoprene, and $k_{2}$ is taken as the average of rate constants for $\mathrm{OH}$ reactions with MACR and MVK. Uncertainties associated with the simplification of $k_{2}$ in calculating the MACR and MVK yields will be discussed shortly. Note that the ozonolysis and $\mathrm{NO}_{3}$-initiated oxidation in total account for less than $6 \%$ of isoprene degradation pathway under current experimental conditions and are neglected in the calculation. The ozonolysis and photolysis in total account for $\sim 6 \%$ of the $\mathrm{C}_{4} \mathrm{H}_{6} \mathrm{O}$ degradation pathway and are neglected here as well.

In the continuous-mode operation, two mass conservation equations are satisfied at steady state:

$$
\begin{aligned}
\frac{\mathrm{d}\left[\mathrm{C}_{5} \mathrm{H}_{8}\right]_{\mathrm{ss}}}{\mathrm{d} t}= & {\left[\mathrm{C}_{5} \mathrm{H}_{8}\right]_{0} / \tau-\left[\mathrm{C}_{5} \mathrm{H}_{8}\right]_{\mathrm{ss}} / \tau } \\
& -k_{1} \cdot[\mathrm{OH}]_{\mathrm{ss}} \cdot\left[\mathrm{C}_{5} \mathrm{H}_{8}\right]_{\mathrm{ss}}=0 \\
\frac{\mathrm{d}\left[\mathrm{C}_{4} \mathrm{H}_{6} \mathrm{O}\right]_{\mathrm{ss}}}{\mathrm{d} t}= & Y_{\mathrm{C}_{4} \mathrm{H}_{6} \mathrm{O}} \cdot k_{1} \cdot[\mathrm{OH}]_{\mathrm{ss}} \cdot\left[\mathrm{C}_{5} \mathrm{H}_{8}\right]_{\mathrm{ss}}-k_{2} \cdot[\mathrm{OH}]_{\mathrm{ss}} \\
& \cdot\left[\mathrm{C}_{4} \mathrm{H}_{6} \mathrm{O}\right]_{\mathrm{ss}}-\left[\mathrm{C}_{4} \mathrm{H}_{6} \mathrm{O}\right]_{\mathrm{ss}} / \tau=0
\end{aligned}
$$

where $\left[\mathrm{C}_{5} \mathrm{H}_{8}\right]_{\mathrm{ss}}$ and $\left[\mathrm{C}_{4} \mathrm{H}_{6} \mathrm{O}\right]_{\mathrm{ss}}$ are the PTR-Q-MS measured steady-state concentrations of isoprene and the sum of MACR and MVK when using the cold trap, respectively, $\left[\mathrm{C}_{5} \mathrm{H}_{8}\right]_{0}$ is the initial concentration of isoprene, and $\tau$ is the chamber mean residence time and can be calculated as the total chamber volume divided by the incoming and outgoing flow rate. The steady-state $\mathrm{OH}$ radical concentration $\left([\mathrm{OH}]_{\mathrm{ss}}\right)$ can be derived by solving Eq. (2). The calculated $[\mathrm{OH}]_{\mathrm{ss}}$ $\left(3.13 \times 10^{6} \mathrm{molec} \mathrm{cm}^{-3}\right)$ is $12 \%$ higher than the model prediction $\left(2.74 \times 10^{6} \mathrm{molec} \mathrm{cm}^{-3}\right)$. The molar yield of the sum of MACR and MVK from isoprene $\mathrm{OH}$ oxidation pathway in the presence of $\sim 0.45 \mathrm{ppb} \mathrm{NO}$ is thus given by Eq. (4) and calculated as $76.7 \pm 5.8 \%$ :

$$
\begin{aligned}
Y_{\mathrm{C}_{4} \mathrm{H}_{6} \mathrm{O}=} & \frac{\left[\mathrm{C}_{4} \mathrm{H}_{6} \mathrm{O}\right]_{\mathrm{ss}}+k_{2} \cdot[\mathrm{OH}]_{\mathrm{ss}} \cdot \tau \cdot\left[\mathrm{C}_{4} \mathrm{H}_{6} \mathrm{O}\right]_{\mathrm{ss}}}{k_{1} \cdot[\mathrm{OH}]_{\mathrm{ss}} \cdot \tau \cdot\left[\mathrm{C}_{5} \mathrm{H}_{8}\right]_{\mathrm{ss}}} \\
& \times f_{\beta-\mathrm{ISOPOO}+\mathrm{NO} .}
\end{aligned}
$$

Here a $5.8 \%$ uncertainty originates from the assumption that $\mathrm{MACR}+\mathrm{OH}$ and $\mathrm{MVK}+\mathrm{OH}$ proceed with equal reaction rate, although the rate constant for $\mathrm{MVK}+\mathrm{OH}$ is $\sim 31 \%$ lower than that of MACR $+\mathrm{OH}$. Another potential uncertainty relates to the accuracy of the simulated steady-state $\mathrm{HO}_{2}$ and $\mathrm{RO}_{2}$ concentrations and the contribution of $\beta$-ISOPOO $+\mathrm{HO}_{2}$ and $\beta$-ISOPOO $+\mathrm{RO}_{2}$ reaction pathways to the overall $\beta$-ISOPOO fate. The fraction of $\beta$ ISOPOO radicals that reacts with $\mathrm{NO}\left(f_{\beta \text {-ISOPOO+NO }}\right)$ was predicted as 0.88 , which was used here to scale the final MACR + MVK yield, see Eq. (4).

In summary, the measured yield of the sum of MACR and MVK in this study is close to that reported by Karl et al. (2006) and Liu et al. (2013), but $\sim 27-52 \%$ higher than the majority of previous measurements performed under high-NO conditions ( $\mathrm{NO}>60 \mathrm{ppb}$ ). This is consistent with the dynamic nature of the six ISOPOO radical isomers that undergo rapid interconversion by addition or removal of $\mathrm{O}_{2}$. In the presence of $\sim 0.45 \mathrm{ppb} \mathrm{NO}$ as performed in this study, lifetimes of the $\beta-1-\mathrm{OH}-2-\mathrm{OO}$ peroxy radical with respect to reaction with $\mathrm{NO}$ and loss of $\mathrm{O}_{2}$ are estimated as 9.4 and $0.2 \mathrm{~s}$, respectively, implying that the rapid interconversion between $\beta$-ISOPOO and $\delta$-ISOPOO radicals essentially governs their distribution; under such conditions, the production of thermodynamically more stable $\beta$-ISOPOO isomers is favored, leading to higher yields of MACR and MVK. Here the reported MACR and MVK yield from isoprene $\mathrm{OH}$ oxidation in the presence of $\sim 0.45 \mathrm{ppb}$ NO represents an illustration of chamber operation at steady-state continuous flow mode for the establishment of certain experimental conditions that are not easily accessible from traditional batch-mode chamber experiments. A complete measurement of first-generation oxidation products from isoprene $\mathrm{OH}$ reaction under a wide range of NO levels (ISOPOO bimolecular lifetimes) will be forthcoming in a future publication.

\subsection{Optimal operating conditions for nighttime chemistry}

Figure 4 shows the model simulated steady-state mixing ratios of $\mathrm{HO}_{2}, \mathrm{NO}_{3}, \mathrm{NO}, \mathrm{NO}_{2}$, and $\mathrm{O}_{3}$ after $16 \mathrm{~h}$ of dark reactions in the chamber as a function of the $\mathrm{HCHO}$ concen- 

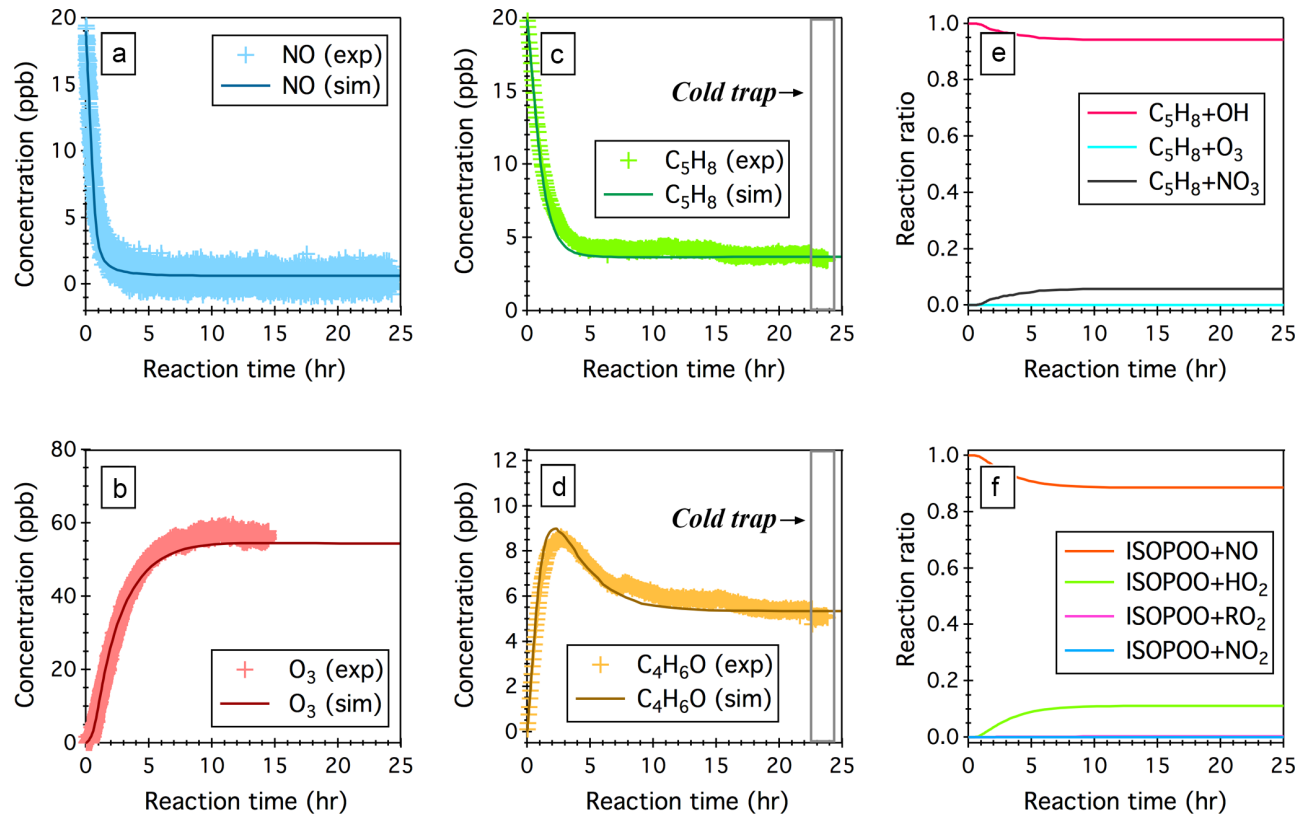

Figure 3. Simulated (sim.) and observed (exp.) temporal profiles of (a) $\mathrm{NO}$, (b) $\mathrm{O}_{3}$, (c) isoprene $\left(\mathrm{C}_{5} \mathrm{H}_{8}\right)$, and (d) the sum of $\mathrm{MACR}$ and MVK $\left(\mathrm{C}_{4} \mathrm{H}_{6} \mathrm{O}\right)$ over $24 \mathrm{~h} \mathrm{OH}$-initiated oxidation of isoprene in the continuous flow mode chamber operation. Also displayed here include (e) simulated fractions of $\mathrm{OH}$ oxidation, ozonolysis, and $\mathrm{NO}_{3}$ oxidation as the removal pathways of isoprene and (f) simulated fractions of ISOPOO radicals that react with $\mathrm{NO}, \mathrm{HO}_{2}, \mathrm{RO}_{2}$, and $\mathrm{NO}_{3}$. Time 0 is the point at which the chamber lights are turned on. Initial experimental conditions are $19 \mathrm{ppb} \mathrm{NO}, 0 \mathrm{ppb} \mathrm{NO} \mathrm{N}_{2}, 0 \mathrm{pp} \mathrm{O}_{3}, 600 \mathrm{pp} \mathrm{H}_{2} \mathrm{O}_{2}$, and $19.9 \mathrm{ppb} \mathrm{C}_{5} \mathrm{H}_{8}$, with continuous input of $600 \mathrm{ppb} \mathrm{H}_{2} \mathrm{O}_{2}, 19 \mathrm{ppb} \mathrm{NO}$, and $19.9 \mathrm{ppb} \mathrm{C}_{5} \mathrm{H}_{8}$ over the course of $24 \mathrm{~h}$ photochemical reactions.
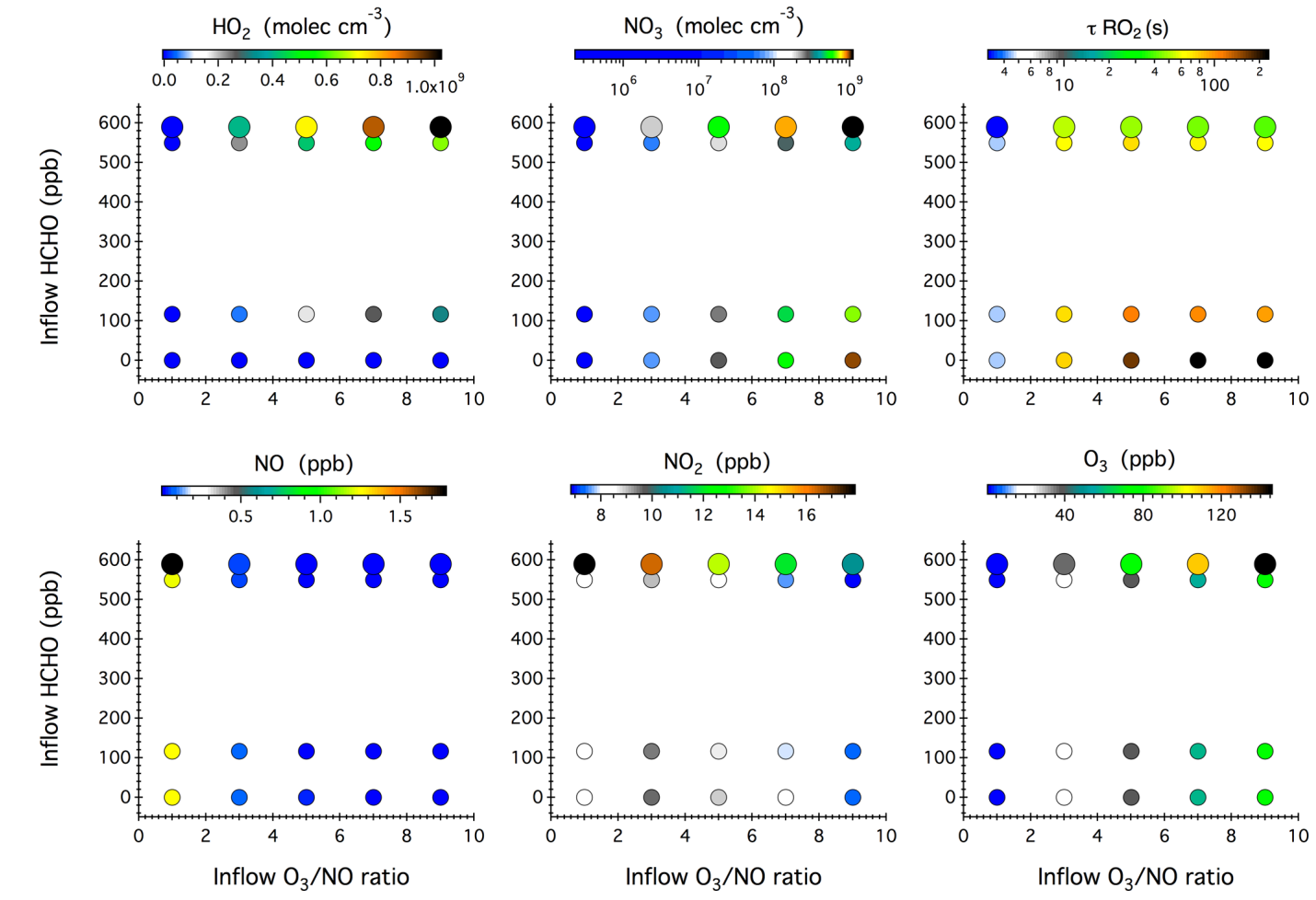

Figure 4. Simulated steady-state mixing ratios of $\mathrm{HO}_{2}, \mathrm{NO}_{3}, \mathrm{NO}, \mathrm{NO}_{2}$, and $\mathrm{O}_{3}$ after $16 \mathrm{~h}$ of dark reactions in the chamber as a function of the concentrations of $\mathrm{HCHO}, \mathrm{NO}$, and $\mathrm{O}_{3}$ in the continuous injection flow. The symbol size denotes different inflow NO concentrations, i.e., 10 and $20 \mathrm{ppb}$. Also given here is the calculated lifetime of an $\mathrm{RO}_{2}$ radical $\left(\tau_{\mathrm{RO}_{2}}\right)$ with respect to reactions with $\mathrm{NO}, \mathrm{NO}_{3}$, and $\mathrm{HO}_{2}$. 
tration and $\mathrm{O}_{3} / \mathrm{NO}$ ratio in the continuous chamber inflow. Blank experiments were compared with simulations in five cases (see Table $\mathrm{S} 1$ in the Supplement). The model captures the evolution patterns of $\mathrm{NO}_{x}$ and $\mathrm{O}_{3}$ well. The observed mixing ratios of $\mathrm{NO}_{2}$ and $\mathrm{O}_{3}$ agree with the simulations to within 11 and $6 \%$, respectively (Fig. S4 in the Supplement).

Compared with the photochemical reaction schemes discussed earlier, the nocturnal chemistry is rather straightforward; that is, the inflow $\mathrm{O}_{3} / \mathrm{NO}$ ratio governs the steadystate concentrations of $\mathrm{NO}_{3}, \mathrm{NO}_{x}$, and $\mathrm{O}_{3}$, while the inflow $\mathrm{HCHO}$ concentration ultimately controls the steadystate $\mathrm{HO}_{2}$ level. Increasing the $\mathrm{O}_{3} / \mathrm{NO}$ ratio from 1 to 9 in the continuous inflow leads to increased $\mathrm{NO}_{3}$ from $2.4 \times 10^{5}$ to $1.1 \times 10^{9} \mathrm{molec}^{-3}$, but decreased NO from $1.8 \mathrm{ppb}$ to $20 \mathrm{ppt}$ and decreased $\mathrm{NO}_{2}$ from 18 to $7 \mathrm{ppb}$. At a fixed inflow $\mathrm{O}_{3} / \mathrm{NO}$ ratio, doubling the $\mathrm{NO}$ and $\mathrm{O}_{3}$ concentrations leads to elevated $\mathrm{NO}_{3}, \mathrm{NO}_{x}$, and $\mathrm{O}_{3}$ by a factor of 2.0-3.2, 1.5-2.0, and 1.4-2.0, respectively. The use of $\mathrm{HCHO}$ as an effective dark $\mathrm{HO}_{2}$ source does not significantly impact the steady-state mixing ratios of $\mathrm{NO}_{x}$ and $\mathrm{O}_{3}$, but slightly weakens the $\mathrm{NO}_{3}$ production.

The calculated $\mathrm{RO}_{2}$ lifetime $\left(\tau_{\mathrm{RO}_{2}}\right)$ with respect to reactions with $\mathrm{NO}, \mathrm{NO}_{3}$, and $\mathrm{HO}_{2}$ at $295 \mathrm{~K}$ ranges from 3 to $225 \mathrm{~s}$. The highest $\tau_{\mathrm{RO}_{2}}$ was achieved in the absence of any $\mathrm{HCHO}$ source and corresponds to a chemical regime that can be employed to study the intramolecular isomerization (autoxidation) pathway of $\mathrm{RO}_{2}$ radicals, if any. Adding a continuous flow of $\mathrm{HCHO}$ to the system leads to the production of $10^{7}-10^{9}$ molec $\mathrm{cm}^{-3} \mathrm{HO}_{2}$ radicals that then constitute a significant sink of $\mathrm{RO}_{2}$ radicals and represents prevailing forest environments during nighttime.

\subsection{Application to $\mathrm{NO}_{3}$-initiated oxidation of isoprene}

$\mathrm{NO}_{3}$-initiated oxidation of isoprene proceeds by the $\mathrm{NO}_{3}$ addition to the carbon double bonds followed by $\mathrm{O}_{2}$ addition, yielding six distinct nitrooxy peroxy radicals (INOO), including two isomers ( $\beta$-INOO) with $\mathrm{O}_{2}$ added on the $\beta$ carbon to the nitrate group (see Fig. $2 \mathrm{~b}$ for schematic illustration). The $\beta$-INOO radicals react further with $\mathrm{NO}_{3}$, $\mathrm{HO}_{2}, \mathrm{NO}$, and $\mathrm{RO}_{2}$, producing nitrooxy alkoxy radicals $(\beta-$ INO) with molar yields of $1.00,0.53,0.97$, and 0.40 , respectively (Wennberg et al., 2018). The further decomposition of $\beta$-INO radicals produces MACR and MVK, together with $\mathrm{HCHO}$ and $\mathrm{NO}_{2}$. Depending on the actual fate of $\beta$-INOO radicals, the yields of $\beta$-INO radicals can then vary from 0.4 to 1.0 , resulting in a distinct distribution of final oxidation products. It is thus important to specify the ultimate fate of INOO radicals during quantification of oxidation products from isoprene reaction with $\mathrm{NO}_{3}$. As an illustration, we performed one continuous-mode experiment that targets on controlling the steady-state fate of INOO radicals to be their reaction with $\mathrm{NO}$ and $\mathrm{HO}_{2}$ (46 and $38 \%$ INOO radicals are predicted to react with $\mathrm{NO}$ and $\mathrm{HO}_{2}$, respectively, as shown in Fig. 5). Note that by adjusting the concentrations and frac- tions of inflow reactants $\left(\mathrm{O}_{3}, \mathrm{NO}, \mathrm{HCHO}\right.$, and $\left.\mathrm{C}_{5} \mathrm{H}_{8}\right)$, different chemical fates and lifetimes of INOO radicals can be achieved.

Figure 5 shows the observed and predicted temporal profiles of $\mathrm{NO}_{x}, \mathrm{O}_{3}, \mathrm{C}_{5} \mathrm{H}_{8}$, and $\mathrm{C}_{4} \mathrm{H}_{6} \mathrm{O}$ over $25 \mathrm{~h}$ of isoprene oxidation by $\mathrm{NO}_{3}$, with continuous input of $10.2 \mathrm{ppb} \mathrm{C}_{5} \mathrm{H}_{8}$, $205 \mathrm{ppb} \mathrm{O}_{3}$, and $59 \mathrm{ppb} \mathrm{NO}$ into the chamber and a balancing outgoing flow at $40 \mathrm{~L} \mathrm{~min}^{-1}$ carrying well-mixed reactants and products. It took $>16 \mathrm{~h}$ to reach steady state for all the species displayed. In general, the model captures the trends of $\mathrm{O}_{3}$ and $\mathrm{NO}$ well, while underpredicting the steady-state $\mathrm{NO}_{2}$ by $\sim 26 \%$. After $\sim 18 \mathrm{~h}$ of dark reaction, the PTRQ-MS sampling tubing was submerged into a cold ethanol bath $\left(-40 \pm 2{ }^{\circ} \mathrm{C}\right)$ to trap artifacts in the PTR-Q-MS measured $\mathrm{C}_{4} \mathrm{H}_{7} \mathrm{O}^{+}(m / z, 71)$ signal. The simulated steady-state concentration of isoprene agrees within $9 \%$ with the measurements. The derived concentration of the sum of MACR and MVK from the measured $\mathrm{C}_{4} \mathrm{H}_{7} \mathrm{O}^{+}$ion intensity upon cold trapping is $\sim 1.1 \mathrm{ppb}$, which is $\sim 129 \%$ higher than the model predictions $(\sim 0.48 \mathrm{ppb})$. This disagreement can be attributed, to a large extent, to the oversimplified representation of the six different INOO radicals as one $\delta$-INOO isomer in the MCMv3.3.1 mechanism. As a result, the production of $\beta$-INOO radical, the important precursor of MACR and MVK, from $\mathrm{NO}_{3}$-initiated oxidation of isoprene is suppressed in the simulations. The measured molar yield of the sum of MACR and MVK is $36.3 \pm 12.1 \%$, with uncertainties arising from the fact that $10.5 \%$ isoprene is predicted to react with $\mathrm{OH}$ as an additional source of MACR and MVK. Using this value, the fraction of $\beta$-INOO over the sum of nitrooxy peroxy radicals is estimated as $48.6 \pm 16.2 \%$, which is close to that $(\sim 46.3 \%)$ reported by Schwantes et al. (2015), although the estimated bimolecular lifetime of INOO radical in that study $(\sim 30 \mathrm{~s})$ is lower than that predicted in the present work $(\sim 50 \mathrm{~s})$. As discussed above, the hydroxyl peroxy radicals produced from $\mathrm{OH}$ oxidation of isoprene could undergo rapid interconversion through addition or removal of $\mathrm{O}_{2}$ at atmospherically relevant lifetimes. This interconversion significantly impacts the subsequent chemistry of individual ISOPOO radical isomers in terms of reaction rates and product distributions. It is likely that the INOO radicals follow similar interconversion due to the small R-OO bond dissociation energy, although no experimental evidence exists. A full examination of the INOO chemistry, i.e., their kinetic and thermodynamic properties as well as their chemical fate at different lifetimes, will be the focus of future studies using this continuous flow chamber operation method.

\section{Conclusions}

We report here the development and characterization of the NCAR Atmospheric Simulation Chamber operated at steady-state continuous flow mode for simulating daytime and nocturnal chemistry under atmospherically relevant NO 

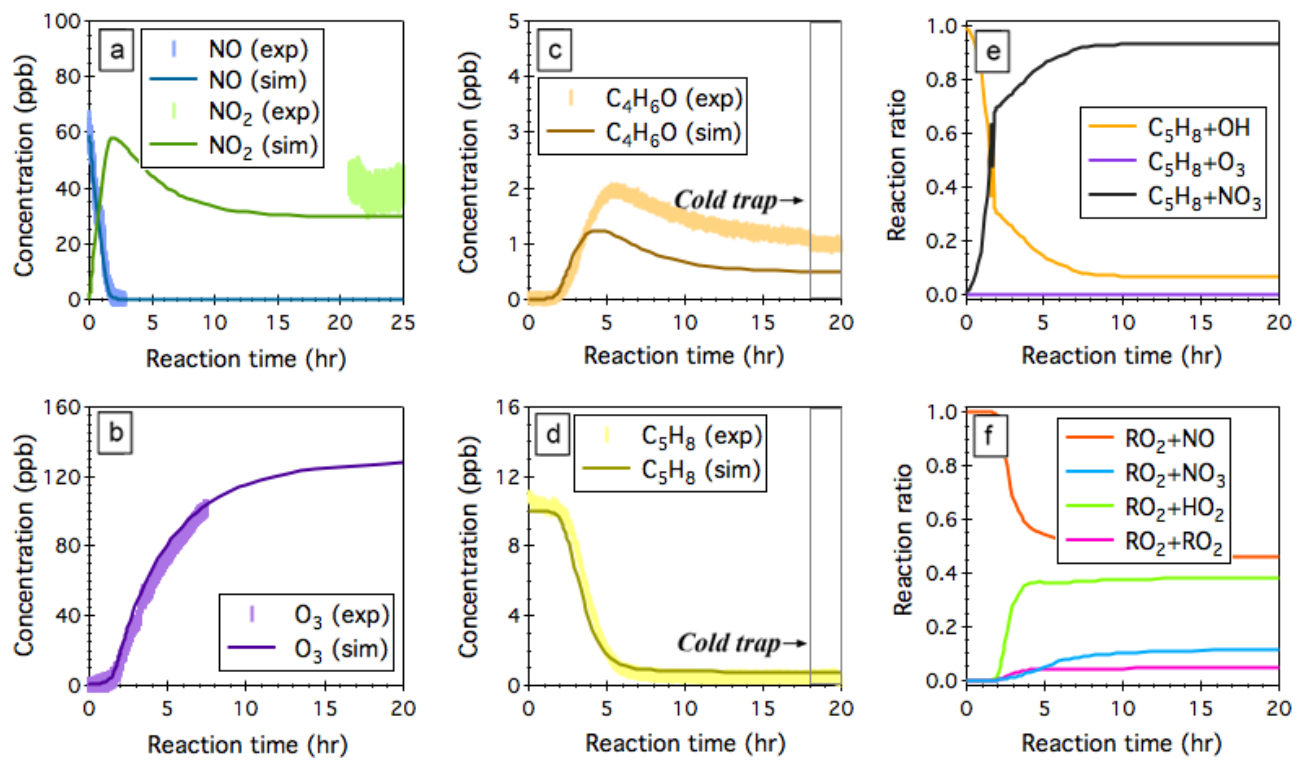

Figure 5. Simulated (sim.) and observed (exp.) evolution patterns of (a) $\mathrm{NO}_{x}$, (b) $\mathrm{O}_{3}$, (c) the sum of MACR and $\mathrm{MVK}\left(\mathrm{C}_{4} \mathrm{H}_{6} \mathrm{O}\right)$, and (d) isoprene $\left(\mathrm{C}_{5} \mathrm{H}_{8}\right)$ over $20 \mathrm{~h} \mathrm{NO}$-initiated oxidation of isoprene under continuous flow mode chamber operation. The fractions of isoprene that reacts with $\mathrm{OH}, \mathrm{O}_{3}$, and $\mathrm{NO}_{3}$ are given in panel (e), and the fractions of INOO radical that undergoes bimolecular reactions with $\mathrm{NO}$, $\mathrm{NO}_{3}, \mathrm{HO}_{2}$, and $\mathrm{RO}_{2}$ are given in panel (f). Initial experimental conditions are $0 \mathrm{ppb} \mathrm{O}_{3}, 59 \mathrm{ppb} \mathrm{NO}_{x}$, and $10.2 \mathrm{ppb} \mathrm{C}_{5} \mathrm{H}_{8}$, with continuous input of $205 \mathrm{ppb} \mathrm{O}_{3}, 59 \mathrm{ppb} \mathrm{NO}$, and $10.2 \mathrm{ppb} \mathrm{C}_{5} \mathrm{H}_{8}$ over the course of $20 \mathrm{~h}$ dark reactions.

levels. The chamber is designed to achieve a well-controlled steady-state environment by continuous inflow of reactants and continuous withdrawal of reactor contents. We use a combination of kinetic modeling and chamber experiments to characterize the "intermediate-NO" chemical regime (tens of ppt to a few ppb) that can be achieved by precisely controlling the inlet reactant concentrations and the mixing/residence timescales of the chamber.

To mimic daytime photochemistry, continuous input of $\mathrm{H}_{2} \mathrm{O}_{2}$ and $\mathrm{NO}$ gases is required, resulting in steady-state $\mathrm{OH}$ mixing ratios of $10^{5}-10^{6}$ molec $\mathrm{cm}^{-3}$ under irradiation. Under such conditions, the lifetime of a peroxy radical with respect to reaction with $\mathrm{NO}$ and $\mathrm{HO}_{2}$ can be extended to $60 \mathrm{~s}$ or even longer, thus providing a unique environment to study all reaction possibilities of $\mathrm{RO}_{2}$ radicals including the intramolecular isomerization (autoxidation) pathway. When studying $\mathrm{OH}$-initiated chemistry, care needs to be taken to avoid a range of experimental conditions (e.g., inflow $\mathrm{H}_{2} \mathrm{O}_{2}>2 \mathrm{ppm}$ and $\mathrm{NO}>20 \mathrm{ppb}$ ) where $\mathrm{NO}_{3}$ oxidation might account for a large fraction of the overall degradation pathway of certain parent hydrocarbons such as alkenes.

To mimic nighttime chemistry, continuous input of $\mathrm{NO}$ (or $\mathrm{NO}_{2}$ ) and $\mathrm{O}_{3}$ is needed to produce steady-state $\mathrm{NO}_{3}$ radicals in the range of $10^{6}-10^{9}$ molec $\mathrm{cm}^{-3}$ in the dark. Under such conditions, an $\mathrm{RO}_{2}$ radical can live up to 4 min prior to finding a bimolecular reaction partner (e.g., $\mathrm{NO}, \mathrm{NO}_{3}$, and $\mathrm{HO}_{2}$ ), which were the dominant fates of $\mathrm{RO}_{2}$ radicals in most batch-mode chamber experiments. Again, the long lifetime of $\mathrm{RO}_{2}$ radicals achieved by the steady-state continuous- mode operation opens an avenue for close examination of $\mathrm{RO}_{2}$ unimolecular (isomerization) pathways in nocturnal environments.

In simulating both daytime and nighttime chemistry with continuous flow operation method, $\mathrm{O}_{3}$ accumulation is unavoidable. The extent to which ozonolysis interferes with $\mathrm{OH}$ - or $\mathrm{NO}_{3}$-initiated oxidation chemistry depends on the steady-state $\mathrm{O}_{3}$ concentration achieved in the chamber and its reactivity towards various parent VOCs. Taking isoprene as an example, ozonolysis accounts for $<1$ and $<0.1 \%$ of the overall isoprene degradation kinetics, respectively, under established steady-state photolytic and dark conditions described above.

In atmospheric chemistry, the terms "zero-NO" vs. "highNO" have been widely used to classify photooxidation conditions and delineate the gas-phase fate of the peroxy radicals $\left(\mathrm{RO}_{2}\right)$ generated from VOCs oxidation (Zhang et al., 2010, 2014b, 2015a; He et al., 2011; Cappa et al., 2013; Zhang and Seinfeld, 2013; Loza et al., 2014; Nguyen et al., 2014a; Schilling Fahnestock et al., 2014; Krechmer et al., 2015; Gordon et al., 2016; Riva et al., 2016; Thomas et al., 2016; Schwantes et al., 2017a, b). In the so-called "highNO" regime, reaction with $\mathrm{NO}$ dominates the fate of $\mathrm{RO}_{2}$ radicals, whereas in the "zero-NO" regime, the $\mathrm{RO}_{2}$ radicals primarily undergo reaction with $\mathrm{HO}_{2}$ and, perhaps to a much lesser degree, self- or cross-combination. The importance of the "intermediate-NO" regime lies in the fact that at sub-ppb levels of $\mathrm{NO}$, the $\mathrm{RO}_{2}+\mathrm{NO}$ and $\mathrm{RO}_{2}+\mathrm{HO}_{2}$ reactions are expected to co-exist and the $\mathrm{RO}_{2}$ radical could survive up 
to several minutes before encountering a partner $\left(\mathrm{NO} / \mathrm{HO}_{2}\right)$ for bimolecular reactions. Under such conditions, the $\mathrm{RO}_{2}$ radical isomers may undergo interconversion by addition or removal of $\mathrm{O}_{2}$ and intramolecular isomerization (autoxidation) through $\mathrm{H}$-shift. Here we use isoprene as an illustrative VOC to explore the fate of $\mathrm{RO}_{2}$ radicals under sub-ppb NO. Future work will focus on detailed characterization of oxidation products from isoprene day- and nighttime chemistry with particular attention given to the controlled $\mathrm{RO}_{2}$ fates and lifetimes.

Data availability. Data presented in this paper are available upon request to the corresponding author.

Supplement. The supplement related to this article is available online at: https://doi.org/10.5194/amt-11-2537-2018-supplement.

Competing interests. The authors declare that they have no conflict of interest.

Acknowledgements. The National Center for Atmospheric Research is operated by the University Corporation for Atmospheric Research, under the sponsorship of the National Science Foundation.

Edited by: Andreas Hofzumahaus

Reviewed by: Paul Seakins and one anonymous referee

\section{References}

Atkinson, R., Baulch, D. L., Cox, R. A., Crowley, J. N., Hampson, R. F., Hynes, R. G., Jenkin, M. E., Rossi, M. J., Troe, J., and IUPAC Subcommittee: Evaluated kinetic and photochemical data for atmospheric chemistry: Volume II - gas phase reactions of organic species, Atmos. Chem. Phys., 6, 3625-4055, https://doi.org/10.5194/acp-6-3625-2006, 2006.

Bloss, C., Wagner, V., Bonzanini, A., Jenkin, M. E., Wirtz, K., Martin-Reviejo, M., and Pilling, M. J.: Evaluation of detailed aromatic mechanisms (MCMv3 and MCMv3.1) against environmental chamber data, Atmos. Chem. Phys., 5, 623-639, https://doi.org/10.5194/acp-5-623-2005, 2005.

Cappa, C. D., Zhang, X., Loza, C. L., Craven, J. S., Yee, L. D., and Seinfeld, J. H.: Application of the Statistical Oxidation Model (SOM) to Secondary Organic Aerosol formation from photooxidation of $\mathrm{C}_{12}$ alkanes, Atmos. Chem. Phys., 13, 1591-1606, https://doi.org/10.5194/acp-13-1591-2013, 2013.

Chameides, W. L., Lindsay, R. W., Richardson, J., and Kiang, C. S.: The role of biogenic hydrocarbons in urban photochemical smog: Atlanta as a case study, Science, 241, 1473-1476, 1988.

Crounse, J. D., Paulot, F., Kjaergaard, H. G., and Wennberg, P. O.: Peroxy radical isomerization in the oxidation of isoprene, Phys. Chem. Chem. Phys., 13, 13607-13613, 2011.
Crounse, J. D., Knap, H. C., Ørnsø, K. B., Jørgensen, S., Paulot, F., Kjaergaard, H. G., and Wennberg, P. O.: Atmospheric fate of methacrolein. 1. Peroxy radical isomerization following addition of $\mathrm{OH}$ and $\mathrm{O}_{2}$, J. Phys. Chem. A, 116, 5756-5762, 2012.

Crounse, J. D., Nielsen, L. B., Jørgensen, S., Kjaergaard, H. G., and Wennberg, P. O.: Autoxidation of organic compounds in the atmosphere, J. Phys. Chem. Lett., 4, 3513-3520, 2013.

De Gouw, J. A., Middlebrook, A. M., Warneke, C., Goldan, P. D., Kuster, W. C., Roberts, J. M., Fehsenfeld, F. C., Worsnop, D. R., Canagaratna, M. R., and Pszenny, A. A. P.: Budget of organic carbon in a polluted atmosphere: Results from the New England Air Quality Study in 2002, J. Geophys. Res.-Atmos., 110, D16305, https://doi.org/10.1029/2004JD005623, 2005.

Ehn, M., Thornton, J. A., Kleist, E., Sipilä, M., Junninen, H., Pullinen, I., Springer, M., Rubach, F., Tillmann, R., Lee, B., Lopez-Hilfiker, F., Andres, S., Acir, I.-H., Rissanen, M., Jokinen, T., Schobesberger, S., Kangasluoma, J., Kontkanen, J., Nieminen, T., Kurtén, T., Nielsen, L. B., Jørgensen, S., Kjaergaard, H. G., Canagaratna, M., Maso, M. D., Berndt, T., Petäjä, T., Wahner, A., Kerminen, V.-M., Kulmala, M., Worsnop, D. R., Wildt, J., and Mentel, T. F.: A large source of low-volatility secondary organic aerosol, Nature, 506, 476, https://doi.org/10.1038/nature13032, 2014.

EPA: Data from the 2011 National Emissions Inventory, Version 1, available at: http://www.epa.gov/air-emissions-inventories/ 2011-national-emissions-inventory-nei-data, last access: 2014.

Galloway, M. M., Huisman, A. J., Yee, L. D., Chan, A. W. H., Loza, C. L., Seinfeld, J. H., and Keutsch, F. N.: Yields of oxidized volatile organic compounds during the $\mathrm{OH}$ radical initiated oxidation of isoprene, methyl vinyl ketone, and methacrolein under high-NO ${ }_{x}$ conditions, Atmos. Chem. Phys., 11, 10779-10790, https://doi.org/10.5194/acp-11-10779-2011, 2011.

Goldstein, A. H., Koven, C. D., Heald, C. L., and Fung, I. Y.: Biogenic carbon and anthropogenic pollutants combine to form a cooling haze over the southeastern United States, P. Natl. Acad. Sci. USA, 106, 8835-8840, 2009.

Gordon, H., Sengupta, K., Rap, A., Duplissy, J., Frege, C., Williamson, C., Heinritzi, M., Simon, M., Yan, C., Almeida, J., Tröstl, J., Nieminen, T., Ortega, I. K., Wagner, R., Dunne, E. M., Adamov, A., Amorim, A., Bernhammer, A.-K., Bianchi, F., Breitenlechner, M., Brilke, S., Chen, X., Craven, J. S., Dias, A., Ehrhart, S., Fischer, L., Flagan, R. C., Franchin, A., Fuchs, C., Guida, R., Hakala, J., Hoyle, C. R., Jokinen, T., Junninen, H., Kangasluoma, J., Kim, J., Kirkby, J., Krapf, M., Kürten, A., Laaksonen, A., Lehtipalo, K., Makhmutov, V., Mathot, S., Molteni, U., Monks, S. A., Onnela, A., Peräkylä, O., Piel, F., Petäjä, T., Praplan, A. P., Pringle, K. J., Richards, N. A. D., Rissanen, M. P., Rondo, L., Sarnela, N., Schobesberger, S., Scott, C. E., Seinfeld, J. H., Sharma, S., Sipilä, M., Steiner, G., Stozhkov, Y., Stratmann, F., Tomé, A., Virtanen, A., Vogel, A. L., Wagner, A. C., Wagner, P. E., Weingartner, E., Wimmer, D., Winkler, P. M., Ye, P., Zhang, X., Hansel, A., Dommen, J., Donahue, N. M., Worsnop, D. R., Baltensperger, U., Kulmala, M., Curtius, J., and Carslaw, K. S.: Reduced anthropogenic aerosol radiative forcing caused by biogenic new particle formation, $\mathrm{P}$. Natl. Acad. Sci. USA, 113, 12053-12058, 2016.

He, S., Chen, Z., and Zhang, X.: Photochemical reactions of methyl and ethyl nitrate: a dual role for alkyl nitrates in the nitrogen cycle, Environ. Chem., 8, 529-542, 2011. 
Huang, D. D., Zhang, X., Dalleska, N. F., Lignell, H., Coggon, M. M., Chan, C. M., Flagan, R. C., Seinfeld, J. H., and Chan, C. K.: A note on the effects of inorganic seed aerosol on the oxidation state of secondary organic aerosol $-\alpha$-pinene ozonolysis, J. Geophys. Res.-Atmos., 121, 12476-12483, 2016.

Huang, Y., Zhao, R., Charan, S. M., Kenseth, C. M., Zhang, X., and Seinfeld, J. H.: Unified theory of vapor-wall mass transport in Teflon-walled environmental chambers, Environ. Sci. Technol., 52, 2134-2142, 2018.

Jokinen, T., Berndt, T., Makkonen, R., Kerminen, V.-M., Junninen, H., Paasonen, P., Stratmann, F., Herrmann, H., Guenther, A. B., and Worsnop, D. R.: Production of extremely low volatile organic compounds from biogenic emissions: Measured yields and atmospheric implications, P. Natl. Acad. Sci. USA, 112, 7123-7128, 2015.

Kanakidou, M., Seinfeld, J. H., Pandis, S. N., Barnes, I., Dentener, F. J., Facchini, M. C., Van Dingenen, R., Ervens, B., Nenes, A., Nielsen, C. J., Swietlicki, E., Putaud, J. P., Balkanski, Y., Fuzzi, S., Horth, J., Moortgat, G. K., Winterhalter, R., Myhre, C. E. L., Tsigaridis, K., Vignati, E., Stephanou, E. G., and Wilson, J.: Organic aerosol and global climate modelling: a review, Atmos. Chem. Phys., 5, 1053-1123, https://doi.org/10.5194/acp-5-10532005, 2005.

Karl, M., Dorn, H. P., Holland, F., Koppmann, R., Poppe, D., Rupp, L., Schaub, A., and Wahner, A.: Product study of the reaction of $\mathrm{OH}$ radicals with isoprene in the atmosphere simulation chamber SAPHIR, J. Atmos. Chem., 55, 167-187, 2006.

Kirkby, J., Duplissy, J., Sengupta, K., Frege, C., Gordon, H., Williamson, C., Heinritzi, M., Simon, M., Yan, C., João, A., Tröstl, J., Nieminen, T., Ortega, I. K., Wagner, R., Adamov, A., Amorim, A., Bernhammer, A.-K., Bianchi, F., Breitenlechner, M., Brilke, S., Chen, X., Craven, J., Dias, A., Ehrhart, S., Flagan, R. C., Franchin, A., Fuchs, C., Guida, R., Hakala, J., Hoyle, C. R., Jokinen, T., Junninen, H., Kangasluoma, J., Kim, J., Krapf, M., Kürten, A., Laaksonen, A., Lehtipalo, K., Makhmutov, V., Mathot, S., Molteni, U., Onnela, A., Peräkylä, O., Piel, F., Petäjä, T., Praplan, A. P., Pringle, K., Rap, A., Richards, N. A. D., Riipinen, I., Rissanen, M. P., Rondo, L., Sarnela, N., Schobesberger, S., Scott, C. E., Seinfeld, J. H., Sipilä, M., Steiner, G., Stozhkov, Y., Stratmann, F., Tomé, A., Virtanen, A., Vogel, A. L., Wagner, A. C., Wagner, P. E., Weingartner, E., Wimmer, D., Winkler, P. M., Ye, P., Zhang, X., Hansel, A., Dommen, J., Donahue, N. M., Worsnop, D. R., Baltensperger, U., Kulmala, M., Carslaw, K. S., and Curtius, J.: Ion-induced nucleation of pure biogenic particles, Nature, 533, 521-526, 2016.

Krechmer, J. E., Coggon, M. M., Massoli, P., Nguyen, T. B., Crounse, J. D., Hu, W., Day, D. A., Tyndall, G. S., Henze, D. K., Rivera-Rios, J. C., Nowak, J. B., Kimmel, J. R., III, R. L. M., Stark, H., Jayne, J. T., Sipila, M., Junninen, H., Clair, J. M. S., Zhang, X., Feiner, P. A., Zhang, L., Miller, D. O., Brune, W. H., Keutsch, F. N., Wennberg, P. O., Seinfeld, J. H., Worsnop, D. R., Jimenez, J. L., and Canagaratna, M. R.: Formation of low volatility organic compounds and secondary organic aerosol from isoprene hydroxyhydroperoxide low-NO oxidation, Environ. Sci. Technol., 49, 10330-10339, 2015.

Krechmer, J. E., Pagonis, D., Ziemann, P. J., and Jimenez, J. L.: Quantification of gas-wall partitioning in Teflon environmental chambers using rapid bursts of low-volatility oxidized species generated in situ, Environ. Sci. Technol., 50, 5757-5765, 2016.
Kroll, J. H. and Seinfeld, J. H.: Chemistry of secondary organic aerosol: Formation and evolution of low-volatility organics in the atmosphere, Atmos. Environ., 42, 3593-3624, 2008.

Kurtén, T., Rissanen, M. P., Mackeprang, K., Thornton, J. A., Hyttinen, N., Jørgensen, S., Ehn, M., and Kjaergaard, H. G.: Computational study of hydrogen shifts and ring-opening mechanisms in $\alpha$-pinene ozonolysis products, J. Phys. Chem. A, 119, 1136611375, 2015.

Lambe, A., Massoli, P., Zhang, X., Canagaratna, M., Nowak, J., Daube, C., Yan, C., Nie, W., Onasch, T., Jayne, J., Kolb, C., Davidovits, P., Worsnop, D., and Brune, W.: Controlled nitric oxide production via $\mathrm{O}\left({ }^{1} \mathrm{D}\right)+\mathrm{N}_{2} \mathrm{O}$ reactions for use in oxidation flow reactor studies, Atmos. Meas. Tech., 10, 2283-2298, https://doi.org/10.5194/amt-10-2283-2017, 2017.

Liu, Y. J., Herdlinger-Blatt, I., McKinney, K. A., and Martin, S. T.: Production of methyl vinyl ketone and methacrolein via the hydroperoxyl pathway of isoprene oxidation, Atmos. Chem. Phys., 13, 5715-5730, https://doi.org/10.5194/acp-135715-2013, 2013.

Loza, C. L., Craven, J. S., Yee, L. D., Coggon, M. M., Schwantes, R. H., Shiraiwa, M., Zhang, X., Schilling, K. A., Ng, N. L., Canagaratna, M. R., Ziemann, P. J., Flagan, R. C., and Seinfeld, J. H.: Secondary organic aerosol yields of 12-carbon alkanes, Atmos. Chem. Phys., 14, 1423-1439, https://doi.org/10.5194/acp14-1423-2014, 2014.

McVay, R. C., Zhang, X., Aumont, B., Valorso, R., Camredon, M., La, Y. S., Wennberg, P. O., and Seinfeld, J. H.: SOA formation from the photooxidation of $\alpha$-pinene: systematic exploration of the simulation of chamber data, Atmos. Chem. Phys., 16, 27852802, https://doi.org/10.5194/acp-16-2785-2016, 2016.

Miyoshi, A., Hatakeyama, S., and Washida, N.: OH radical-initiated photooxidation of isoprene: An estimate of global CO production, J. Geophys. Res.-Atmos., 99, 18779-18787, 1994.

Nah, T., McVay, R. C., Zhang, X., Boyd, C. M., Seinfeld, J. H., and $\mathrm{Ng}, \mathrm{N}$. L.: Influence of seed aerosol surface area and oxidation rate on vapor wall deposition and SOA mass yields: a case study with $\alpha$-pinene ozonolysis, Atmos. Chem. Phys., 16, 9361-9379, https://doi.org/10.5194/acp-16-9361-2016, 2016.

Ng, N. L., Chhabra, P. S., Chan, A. W. H., Surratt, J. D., Kroll, J. H., Kwan, A. J., McCabe, D. C., Wennberg, P. O., Sorooshian, A., Murphy, S. M., Dalleska, N. F., Flagan, R. C., and Seinfeld, J. H.: Effect of $\mathrm{NO}_{x}$ level on secondary organic aerosol (SOA) formation from the photooxidation of terpenes, Atmos. Chem. Phys., 7, 5159-5174, https://doi.org/10.5194/acp-7-5159-2007, 2007.

Nguyen, T. B., Coggon, M. M., Bates, K. H., Zhang, X., Schwantes, R. H., Schilling, K. A., Loza, C. L., Flagan, R. C., Wennberg, P. O., and Seinfeld, J. H.: Organic aerosol formation from the reactive uptake of isoprene epoxydiols (IEPOX) onto nonacidified inorganic seeds, Atmos. Chem. Phys., 14, 3497-3510, https://doi.org/10.5194/acp-14-3497-2014, 2014a.

Nguyen, T. B., Crounse, J. D., Schwantes, R. H., Teng, A. P., Bates, K. H., Zhang, X., St. Clair, J. M., Brune, W. H., Tyndall, G. S., Keutsch, F. N., Seinfeld, J. H., and Wennberg, P. O.: Overview of the Focused Isoprene eXperiment at the California Institute of Technology (FIXCIT): mechanistic chamber studies on the oxidation of biogenic compounds, Atmos. Chem. Phys., 14, 1353113549, https://doi.org/10.5194/acp-14-13531-2014, 2014b.

Nguyen, T. B., Bates, K. H., Crounse, J. D., Schwantes, R. H., Zhang, X., Kjaergaard, H. G., Surratt, J. D., Lin, P., Laskin, A., 
and Seinfeld, J. H.: Mechanism of the hydroxyl radical oxidation of methacryloyl peroxynitrate (MPAN) and its pathway toward secondary organic aerosol formation in the atmosphere, Phys. Chem. Chem. Phys., 17, 17914-17926, 2015.

Orlando, J. J. and Tyndall, G. S.: Laboratory studies of organic peroxy radical chemistry: an overview with emphasis on recent issues of atmospheric significance, Chem. Soc. Rev., 41, 62946317, 2012.

Paulson, S. E. and Seinfeld, J. H.: Development and evaluation of a photooxidation mechanism for isoprene, J. Geophys. Res.Atmos., 97, 20703-20715, 1992.

Peeters, J., Müller, J.-F. o., Stavrakou, T., and Nguyen, V. S.: Hydroxyl radical recycling in isoprene oxidation driven by hydrogen bonding and hydrogen tunneling: The upgraded LIM1 mechanism, J. Phys. Chem. A, 118, 8625-8643, 2014.

Petropavlovskikh, I., Shetter, R., Hall, S., Ullmann, K., and Bhartia, P. K.: Algorithm for the charge-coupled-device scanning actinic flux spectroradiometer ozone retrieval in support of the Aura satellite validation, J. Appl. Remote Sens., 1, 013540, https://doi.org/10.1117/1.2802563, 2007.

Riva, M., Budisulistiorini, S. H., Chen, Y., Zhang, Z., D’Ambro, E. L., Zhang, X., Gold, A., Turpin, B. J., Thornton, J. A., and Canagaratna, M. R.: Chemical characterization of secondary organic aerosol from oxidation of isoprene hydroxyhydroperoxides, Environ. Sci. Technol., 50, 9889-9899, 2016.

Rivera-Rios, J. C., Nguyen, T. B., Crounse, J. D., Jud, W., St Clair, J. M., Mikoviny, T., Gilman, J. B., Lerner, B. M., Kaiser, J. B., and Gouw, J. d.: Conversion of hydroperoxides to carbonyls in field and laboratory instrumentation: Observational bias in diagnosing pristine versus anthropogenically controlled atmospheric chemistry, Geophys. Res. Lett., 41, 86458651, 2014.

Rollins, A. W., Browne, E. C., Min, K. E., Pusede, S. E., Wooldridge, P. J., Gentner, D. R., Goldstein, A. H., Liu, S., Day, D. A., and Russell, L. M.: Evidence for $\mathrm{NO}_{x}$ control over nighttime SOA formation, Science, 337, 1210-1212, 2012.

Ruppert, L. and Becker, K. H.: A product study of the OH radicalinitiated oxidation of isoprene: Formation of C 5-unsaturated diols, Atmos. Environ., 34, 1529-1542, 2000.

Schilling Fahnestock, K. A., Yee, L. D., Loza, C. L., Coggon, M. M., Schwantes, R., Zhang, X., Dalleska, N. F., and Seinfeld, J. H.: Secondary organic aerosol composition from C12 alkanes, J. Phys. Chem. A, 119, 4281-4297, 2014.

Schwantes, R. H., Teng, A. P., Nguyen, T. B., Coggon, M. M., Crounse, J. D., St. Clair, J. M., Zhang, X., Schilling, K. A., Seinfeld, J. H., and Wennberg, P. O.: Isoprene $\mathrm{NO}_{3}$ oxidation products from the $\mathrm{RO}_{2}+\mathrm{HO}_{2}$ Pathway, J. Phys. Chem. A, 119, 10158-10171, 2015.

Schwantes, R. H., McVay, R. C., Zhang, X., Coggon, M. M., Lignell, H., Flagan, R. C., Wennberg, P. O., and Seinfeld, J. H.: Science of the environmental chamber, Adv. Atmos. Chem., 1, 1-93, 2017a.

Schwantes, R. H., Schilling, K. A., McVay, R. C., Lignell, H., Coggon, M. M., Zhang, X., Wennberg, P. O., and Seinfeld, J. H.: Formation of highly oxygenated low-volatility products from cresol oxidation, Atmos. Chem. Phys., 17, 3453-3474, https://doi.org/10.5194/acp-17-3453-2017, 2017b.
Shilling, J. E., Chen, Q., King, S. M., Rosenoern, T., Kroll, J. H., Worsnop, D. R., McKinney, K. A., and Martin, S. T.: Particle mass yield in secondary organic aerosol formed by the dark ozonolysis of $\alpha$-pinene, Atmos. Chem. Phys., 8, 2073-2088, https://doi.org/10.5194/acp-8-2073-2008, 2008.

Shilling, J. E., Zaveri, R. A., Fast, J. D., Kleinman, L., Alexander, M. L., Canagaratna, M. R., Fortner, E., Hubbe, J. M., Jayne, J. T., Sedlacek, A., Setyan, A., Springston, S., Worsnop, D. R., and Zhang, Q.: Enhanced SOA formation from mixed anthropogenic and biogenic emissions during the CARES campaign, Atmos. Chem. Phys., 13, 2091-2113, https://doi.org/10.5194/acp-132091-2013, 2013.

Singh, H. B. and Hanst, P. L.: Peroxyacetyl nitrate (PAN) in the unpolluted atmosphere: An important reservoir for nitrogen oxides, Geophys. Res. Lett., 8, 941-944, 1981.

Sprengnether, M., Demerjian, K. L., Donahue, N. M., and Anderson, J. G.: Product analysis of the $\mathrm{OH}$ oxidation of isoprene and 1, 3-butadiene in the presence of NO, J. Geophys. Res.-Atmos., 107, 4268, https://doi.org/10.1029/2001JD000716, 2002.

Surratt, J. D., Chan, A. W. H., Eddingsaas, N. C., Chan, M., Loza, C. L., Kwan, A. J., Hersey, S. P., Flagan, R. C., Wennberg, P. O., and Seinfeld, J. H.: Reactive intermediates revealed in secondary organic aerosol formation from isoprene, $\mathrm{P}$. Natl. Acad. Sci. USA, 107, 6640-6645, 2010.

Teng, A. P., Crounse, J. D., and Wennberg, P. O.: Isoprene peroxy radical dynamics, J. Am. Chem. Soc., 139, 5367-5377, 2017.

Thomas, D. A., Coggon, M. M., Lignell, H., Schilling, K. A., Zhang, X., Schwantes, R. H., Flagan, R. C., Seinfeld, J. H., and Beauchamp, J. L.: Real-time studies of iron oxalate-mediated oxidation of glycolaldehyde as a model for photochemical aging of aqueous tropospheric aerosols, Environ. Sci. Technol., 50, 12241-12249, 2016.

Tuazon, E. C. and Atkinson, R.: A product study of the gas-phase reaction of Isoprene with the $\mathrm{OH}$ radical in the presence of $\mathrm{NO}_{x}$, Int. J. Chem. Kinet., 22, 1221-1236, 1990.

Wennberg, P. O., Bates, K. H., Crounse, J. D., Dodson, L. G., McVay, R. C., Mertens, L. A., Nguyen, T. B., Praske, E., Schwantes, R. H., Smarte, M. D., St Clair, J. M., Teng, A. P., Zhang, X., and Seinfeld, J. H.: Gas-phase reactions of isoprene and its major oxidation products, Chem. Rev., 118, 3337-3390, https://doi.org/10.1021/acs.chemrev.7b00439, 2018.

$\mathrm{Xu}$, L., Guo, H., Boyd, C. M., Klein, M., Bougiatioti, A., Cerully, K. M., Hite, J. R., Isaacman-VanWertz, G., Kreisberg, N. M., and Knote, C.: Effects of anthropogenic emissions on aerosol formation from isoprene and monoterpenes in the southeastern United States, P. Natl. Acad. Sci. USA, 112, 37-42, 2015.

Zhang, X. and Seinfeld, J. H.: A functional group oxidation model (FGOM) for SOA formation and aging, Atmos. Chem. Phys., 13, 5907-5926, https://doi.org/10.5194/acp-13-5907-2013, 2013.

Zhang, X., Chen, Z. M., and Zhao, Y.: Laboratory simulation for the aqueous OH-oxidation of methyl vinyl ketone and methacrolein: significance to the in-cloud SOA production, Atmos. Chem. Phys., 10, 9551-9561, https://doi.org/10.5194/acp10-9551-2010, 2010.

Zhang, X., Cappa, C. D., Jathar, S. H., McVay, R. C., Ensberg, J. J., Kleeman, M. J., and Seinfeld, J. H.: Influence of vapor wall loss in laboratory chambers on yields of secondary organic aerosol, $\mathrm{P}$. Natl. Acad. Sci. USA, 111, 5802-5807, 2014a. 
Zhang, X., Schwantes, R. H., Coggon, M. M., Loza, C. L., Schilling, K. A., Flagan, R. C., and Seinfeld, J. H.: Role of ozone in SOA formation from alkane photooxidation, Atmos. Chem. Phys., 14, 1733-1753, https://doi.org/10.5194/acp-14-1733-2014, 2014b.

Zhang, X., McVay, R. C., Huang, D. D., Dalleska, N. F., Aumont, B., Flagan, R. C., and Seinfeld, J. H.: Formation and evolution of molecular products in $\alpha$-pinene secondary organic aerosol, P. Natl. Acad. Sci. USA, 112, 14168-14173, 2015 a.

Zhang, X., Schwantes, R. H., McVay, R. C., Lignell, H., Coggon, M. M., Flagan, R. C., and Seinfeld, J. H.: Vapor wall deposition in Teflon chambers, Atmos. Chem. Phys., 15, 4197-4214, https://doi.org/10.5194/acp-15-4197-2015, 2015 b.
Zhang, X., Lambe, A. T., Upshur, M. A., Brooks, W. A., Gray Beì, A., Thomson, R. J., Geiger, F. M., Surratt, J. D., Zhang, Z., and Gold, A.: Highly oxygenated multifunctional compounds in $\alpha$-pinene secondary organic aerosol, Environ. Sci. Technol., 51, 5932-5940, 2017.

Ziemann, P. J. and Atkinson, R.: Kinetics, products, and mechanisms of secondary organic aerosol formation, Chem. Soc. Rev., 41, 6582-6605, 2012. 